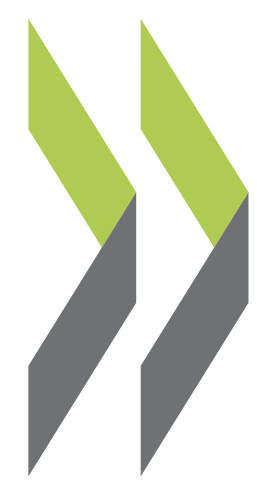

OECD Economics Department Working Papers No. 1543

\title{
Using probit models \\ of downturn risk to calibrate GDP Fan charts for New \\ Zealand
}

Nikki Kergozou, David Turner 


\section{USING PROBIT MODELS OF DOWNTURN RISK TO CALIBRATE GDP FAN CHARTS FOR NEW ZEALAND}

ECONOMICS DEPARTMENT WORKING PAPERS NO. 1543

\section{By Nikki Kergozou and David Turner}

OECD Working Papers should not be reported as representing the official views of the OECD or of its member countries. The opinions expressed and arguments employed are those of the author(s).

Authorised for publication by Alain de Serres, Deputy Director, Policy Studies Branch, Economics Department.

All Economics Department Working Papers are available at www.oecd.org/eco/workingpapers.

JT03443910 
OECD Working Papers should not be reported as representing the official views of the OECD or of its member countries. The opinions expressed and arguments employed are those of the author(s).

Working Papers describe preliminary results or research in progress by the author(s) and are published to stimulate discussion on a broad range of issues on which the OECD works.

Comments on Working Papers are welcomed, and may be sent to OECD Economics Department, 2 rue André Pascal, 75775 Paris Cedex 16, France, or by e-mail to eco.contact@oecd.org.

All Economics Department Working Papers are available at www.oecd.org/eco/workingpapers.

On 3 May 2018, the OECD Council invited Lithuania to become a Member. At the time of preparation, the deposit of Lithuania's instrument of accession to the OECD Convention was pending and therefore Lithuania does not appear in the list of OECD Members and is not included in the OECD zone aggregates.

On 25 May 2018, the OECD Council invited Colombia to become a Member. At the time of preparation, the deposit of Colombia's instrument of accession to the OECD Convention was pending and therefore Colombia does not appear in the list of OECD Members and is not included in the OECD zone aggregates.

This document and any map included herein are without prejudice to the status of or sovereignty over any territory, to the delimitation of international frontiers and boundaries and to the name of any territory, city or area.

The statistical data for Israel are supplied by and under the responsibility of the relevant Israeli authorities. The use of such data by the OECD is without prejudice to the status of the Golan Heights, East Jerusalem and Israeli settlements in the West Bank under the terms of international law.

Latvia was not an OECD member at the time of preparation of this paper. Accordingly, Latvia is not included in the list of OECD countries and is not included in the area totals.

\section{(C) OECD (2019)}

You can copy, download or print OECD content for your own use, and you can include excerpts from OECD publications, databases and multimedia products in your own documents, presentations, blogs, websites and teaching materials, provided that suitable acknowledgment of OECD as source and copyright owner is given. All requests for commercial use and translation rights should be submitted to rights@oecd.org 


\section{ABSTRACT/RÉSUMÉ \\ Using probit models of downturn risk to calibrate GDP fan charts for New Zealand}

Macroeconomic forecasters typically forecast fewer recessions than the number experienced, which means economic growth tends to be over-predicted on average. Consequently, forecast errors are not normally distributed, making it difficult to convey the uncertainty and risks based on the historical forecast track record. To characterise this risk, recent OECD work constructed fan charts parameterised on historical forecast errors and the probability of a future downturn estimated from a probit model comprising a range of potential macroeconomic and financial early warning indicators. As the probability of a downturn increases the associated fan chart is wider, reflecting increased uncertainty, and more skewed to the downside, reflecting greater downside risks. This paper applies this methodology to New Zealand; although one important difference compared to other OECD economies is that the time span of macroeconomic data without major structural change is significantly shorter. Forecast errors for GDP by the OECD, Reserve Bank of New Zealand and New Zealand Treasury all appear to be non-normally distributed. Fan charts for GDP forecasts from the mid-year 2018 OECD Economic Outlook are symmetric due to the low probability of a downturn. Fan charts estimated for the period preceding the global financial crisis using currently-available data have a downwards skew. However, those estimated using data only available in the lead up to the crisis have many insignificant coefficients, likely due to the structural changes that have occurred in the New Zealand economy since the 1980s.

JEL Classification: E58, E17, E65, E66, GO1, E62, E63

Keywords: fan charts, economic forecasts, uncertainty, risk, downturn, New Zealand.

$* * * * *$

\section{Utiliser des modèles probit de crise sévère pout calibrer les graphiques en éventail du PIB de la Nouvelle-Zélande}

Les macro-économistes prédisent habituellement moins de récessions qu'il n'en arrive, signifiant que la croissance économique tend à être surévaluée. En conséquence, les erreurs de prévision ne sont pas distribuées normalement, ce qui rend difficile la communication autour de l'incertitude et des risques basés sur l'historique des prévisions. Pour définir ce risque, de récents travaux de l'OCDE ont construit des graphiques en éventail paramétrés par les erreurs de prévisions passés et par la probabilité d'une crise future, estimée grâce à un modèle probit comprenant un ensemble d'indicateurs macroéconomiques et financiers. Avec l'augmentation de la probabilité d'une crise, le graphique en éventail devient plus large, reflétant une incertitude croissante, et plus déformé vers le bas, reflétant de plus grands risques à la baisse. Ce papier applique cette méthodologie à la Nouvelle-Zélande; néanmoins une différence de taille comparée aux autres pays de l'OCDE est que la période de disponibilité des données macroéconomiques sans changement structurel majeur est beaucoup plus courte. Les erreurs de prévisions du PIB de l'OCDE, de la Banque Centrale, et du Trésor néo-zélandais ne sont pas normalement distribuées. Les graphiques en éventail des prévisions du PIB des Perspectives Économiques de l'OCDE de mi-2018 sont symétriques dus à la faible probabilité d'une crise. Les graphiques en éventail estimés avec des données actuelles pour la période précédant la Crise ont un biais négatif, mais l'utilisation de données disponibles à cette époque ne permet pas d'obtenir des coefficients significatifs, probablement à cause des changements structurels qui ont eu lieu dans l'économie néo-zélandaise depuis les années 1980.

Codes JEL: E58, E17, E65, E66, GO1, E62, E63

Mots clés : graphique en éventail, prévisions économiques, incertitude, risque, crise, NouvelleZélande. 


\section{Table of contents}

Using Probit Models of Downturn Risk to Calibrate GDP Fan Charts for New Zealand............... 5

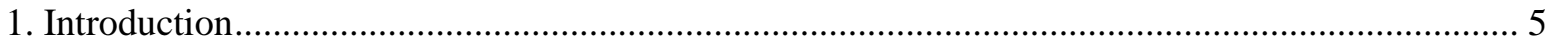

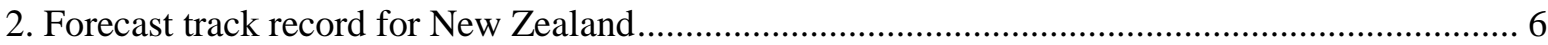

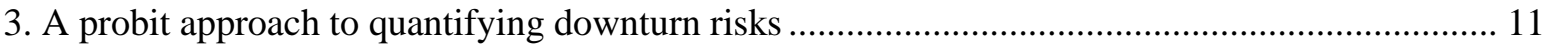

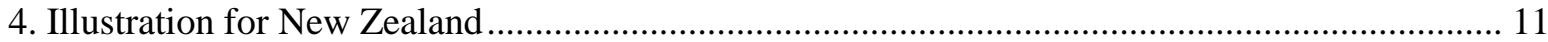

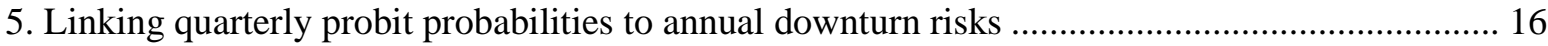

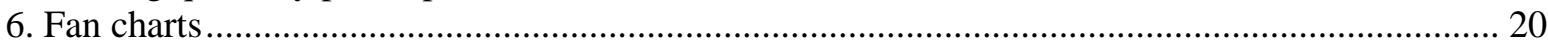

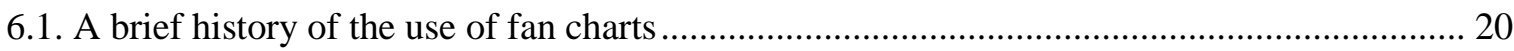

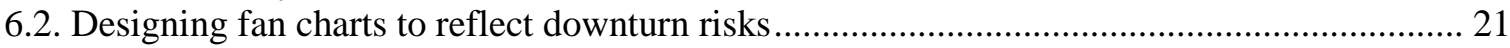

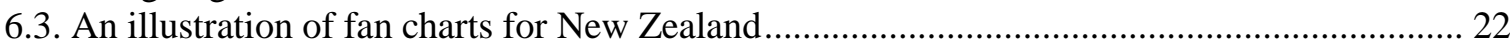

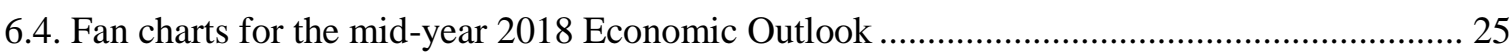

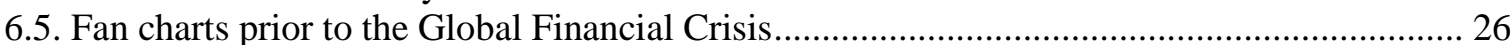

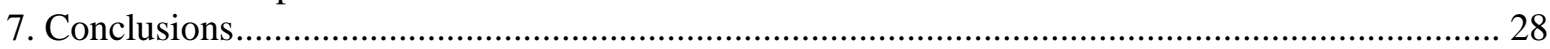

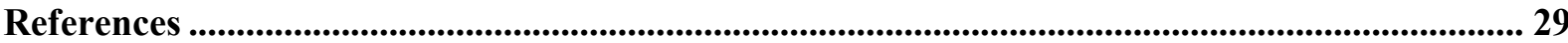

Annex A. Additional descriptive statistics and probit regressions...................................................... 32

\section{Tables}

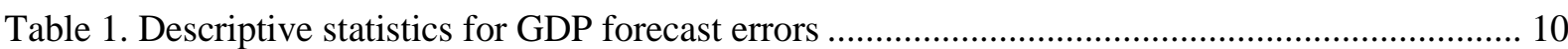

Table 2. Downturn episodes and classical recessions in New Zealand .............................................. 12

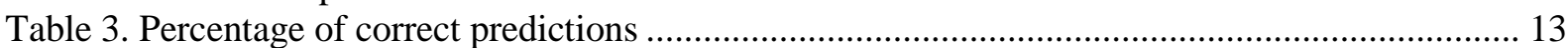

Table 4. Probit regressions of a severe downturn in NZ at different horizons ..................................... 15

Table 5. Regressions of forecast errors for New Zealand on downturn probabilities ........................... 24

\section{Figures}

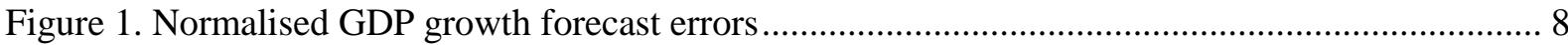

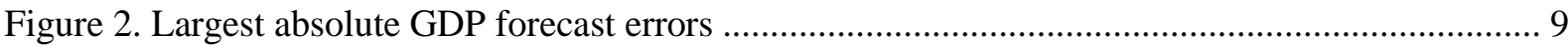

Figure 3. Relating quarterly probit probabilities to annual probabilities.............................................. 17

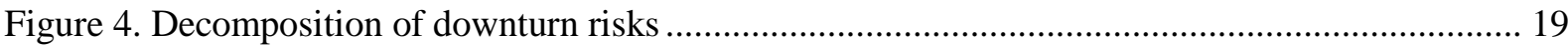

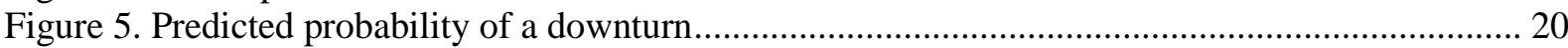

Figure 6. Fan charts for the mid-year 2018 Economic Outlook NZ GDP growth forecast ................... 26

Figure 7. Fan charts for the mid-year 2008 Economic Outlook NZ GDP growth forecast ................... 27

Figure 8. Fan charts for the year-end 2007 Economic Outlook NZ GDP growth forecast.................... 28 


\title{
Using Probit Models of Downturn Risk to Calibrate GDP Fan Charts for New Zealand
}

\author{
Nikki Kergozou and David Turner ${ }^{1}$
}

\section{Introduction}

1. Macroeconomic forecasters typically forecast many fewer recessions than the number experienced. Given that these forecasters do not under-predict during recoveries, over a long forecast track record economic growth tend to be over-predicted on average, with the largest forecast errors corresponding to over-predictions during downturn periods. Consequently, forecast errors are often not normally distributed, making it difficult to convey the uncertainty and risks around GDP growth forecasts based on the historical forecast track record.

2. Recent OECD work has proposed methods to characterise this risk from nonnormally distributed forecast errors by constructing fan charts that are parameterised on historical forecasts and whether the economy is in a 'safe' regime or a 'downturn-risk' regime (Turner, 2017). To identify the two regimes, use is made of previous OECD work on early warning indicators of prospective downturns (Hermansen and Röhn, 2016). When an early warning indicator is 'flashing', implying that the economy is in a downturn-risk regime, the associated fan chart is wider, reflecting increased uncertainty, and also skewed, reflecting greater downside risks. In a safe regime, when the early warning indicators are not flashing, the fan chart is symmetric and narrower relative to both the downturn-risk regime and to what it would be if the dispersion was calculated with respect to the entire forecast track record with no distinction between regimes.

3. Subsequent OECD work developed this methodology further using the predicted probability of a future downturn from a probit model, which includes a variety of early warning indicators on prospective downturns (Turner et al., 2018). This probability is then combined with historical forecast errors to parameterise the fan charts. One of the benefits of this approach, compared to using the binary early warning indicators, is that it allows a gradual transition in the skewness of the fan chart, rather than 'jumping' from symmetry to extreme skewness. It also facilitates the use of several variables to assess the downturn risk. This method was first illustrated for the United Kingdom whereas the current paper applies the same methodology to New Zealand.

4. The remainder of the paper is organised as follows. Section 2 investigates the distribution of the OECD's forecast errors for New Zealand GDP in addition to those of the Reserve Bank of New Zealand (RBNZ) and the New Zealand Treasury (Treasury). The over-prediction bias appears to hold for New Zealand for forecast errors from all

\footnotetext{
${ }^{1}$ Nikki Kergozou was an intern at the OECD Economics Department and is a Masters student at the Paris School of Economics and David Turner is Head of the Macroeconomic Analysis Division in the Economics Department at the OECD. They would like to thank Andrew Barker, Vincent Koen and participants at a joint Reserve Bank of New Zealand and New Zealand Treasury presentation for comments on earlier versions of this paper, with the usual disclaimer. Particular thanks to Thomas Chalaux and Hermes Morgavi for continuous encouragement and advice, especially in terms of data support and generating the fan chart graphics, and Veronica Humi for editorial support.
} 
organisations. Section 3 describes the approach to estimating a probit model for predicting a future downturn in New Zealand. A range of macroeconomic and financial variables are found to be associated with an increased risk of a downturn. Section 4 explains how the quarterly probit probabilities of a downturn are converted into a form which can be more easily related to annual forecast errors. Section 5 outlines the history of the use of fan charts and how the probit probabilities of a downturn are used to parameterise fan charts around forecasts of GDP growth. Fan charts are illustrated for the GDP forecasts from the Spring/mid-year 2018 OECD Economic Outlook and for the Economic Outlooks directly preceding the global financial crisis (GFC). Section 6 concludes.

\section{Forecast track record for New Zealand}

5. Macroeconomic forecasters typically forecast fewer recessions than the number experienced. Forecasts for OECD countries published in the OECD Economic Outlook are typical; since 1991, less than 10\% of forecasts published in May or June correctly identified a recession in the following year (Turner et al., 2018). This poor forecasting performance similarly holds for New Zealand. Neither the OECD, the RBNZ or the Treasury has published forecasts in May or June either correctly or incorrectly predicting a recession in New Zealand in the following year. ${ }^{2}$

6. Given that these forecasters do not under-predict during recoveries, over a long forecast track record, forecast errors tend to be biased towards over-prediction, with the largest outliers corresponding to downturn periods. As such, the distribution of OECD forecast errors for all OECD countries cannot be characterised by a normal distribution for forecast horizons beyond the current year (Turner et al., 2018).

7. This section investigates the distribution of GDP forecast errors for New Zealand by the OECD, the RBNZ and the Treasury. ${ }^{3}$ The OECD forecasts expenditure GDP; so OECD forecast errors are calculated using this approach. However, Statistics New Zealand, the RBNZ and the Treasury focus on production GDP; so RBNZ and Treasury forecast errors are calculated using this approach.

8. The forecasts are selected from those published in either May or June and November or December. The selection of these publication dates ensures that the forecasts of each organisation are as comparable as possible. ${ }^{4}$ The time frame chosen reflects the forecast data that are available electronically. The forecasts analysed here are those detailed in the following publications:

\footnotetext{
${ }^{2}$ Based on forecasts from the OECD Spring Economic Outlook from 1982 to 2017, the RBNZ May or June Monetary Policy Statement from 1996 to 2017 and the Treasury Budget Economic and Fiscal Update from 2001 to 2017. For this statement, a 'recession' is defined as negative growth on a yearon-year calendar basis.

${ }^{3}$ Recent OECD work showed that for major economies there is little difference between the forecast errors from the OECD, the International Monetary Fund or Consensus (Turner, 2018). This result is assumed to hold for New Zealand.

4 The OECD and Treasury release forecasts biannually. The RBNZ publishes two additional Monetary Policy Statements each year.
} 
- OECD Spring Economic Outlook from 1981, the RBNZ May or June Monetary Policy Statement from 1995 and the Treasury Budget Economic and Fiscal Update from 2001. These forecasts will be referred to as the 'mid-year' forecasts.

- OECD Autumn Economic Outlook from 1979 for the year-ahead horizon and from 1987 for the two-year-ahead horizon, the RBNZ November or December Monetary Policy Statement from 1995 and the Treasury Half Yearly Economic and Fiscal Update from 2001. These forecasts will be referred to as the 'year-end' forecasts.

9. The GDP outturns used to calculate the forecast errors are those published in the mid-year Economic Outlook in the year following the release of the data. For example, the GDP outturn used for 2017 is that published in the mid-year Economic Outlook in 2018. The use of the historical rather than the current revised GDP outturn ensures that the forecast errors reflect the information that was available when the forecast was made. ${ }^{5}$

10. The root-mean-square error (RMSE) of forecast errors across forecast horizons and organisations ranges from between 1.4 to 1.8 (Table 1). However, the RMSE varies less across organisations when compared over the same time period (Table A1 and A2 in Annex A). The over-prediction bias appears to hold for New Zealand across all three organisations. Although formal tests do not reject normality, likely a result of the limited sample size, an informal "eye-ball" test tends to reject a normal distribution. In particular:

- Visually, histograms of forecast errors appear to be skewed to the left (Figure 1).

- The largest absolute forecast errors are typically over-predictions, as seen by the red bars in Figure 2, with virtually all of these over-predictions, particularly at longer forecast horizons, occurring during a downturn period. ${ }^{6}$

- The majority of forecast errors greater than double the root mean square error (RMSE) are over-predictions occurring during downturn periods year (Table 1). ${ }^{7}$

- The mean forecast error is negative for all organisations (Table 1).

\footnotetext{
${ }^{5}$ Forecast errors are sensitive to the vintage of outturn data they are judged against and while there is no obviously "correct" vintage to use, the use of the very latest vintage of outturns runs the risk of introducing "false errors" due to possible changes in the conceptual basis of GDP. The calculation of forecast errors for year $\mathrm{T}$ using the outturns published in the mid-year Economic Outlook published in the following year $(\mathrm{T}+1)$ is consistent with previous OECD forecasting evaluation exercises. Moreover, sensitivity testing suggests that use of later vintages of outturn data $-(\mathrm{T}+2)$, $(\mathrm{T}+3)$ or $(\mathrm{T}+4)$ - does not greatly influence the parameterisation of the fan charts described below (Turner and Chalaux, 2019).

${ }^{6}$ Although 2011 is not a downturn period, the downturn in 2010Q3-Q4 significantly affects the annual calculation of errors for 2011. As such, it is included as a downturn year. For more information on this calculation see Cross and Wyman (2011).

${ }^{7}$ There was an under-prediction error in 1984, where growth surprised at $4.9 \%$.
} 
Figure 1. Normalised GDP growth forecast errors

(i) OECD (ii) RBNZ (iii) The Treasury

(A) Current-year forecast errors published mid-year
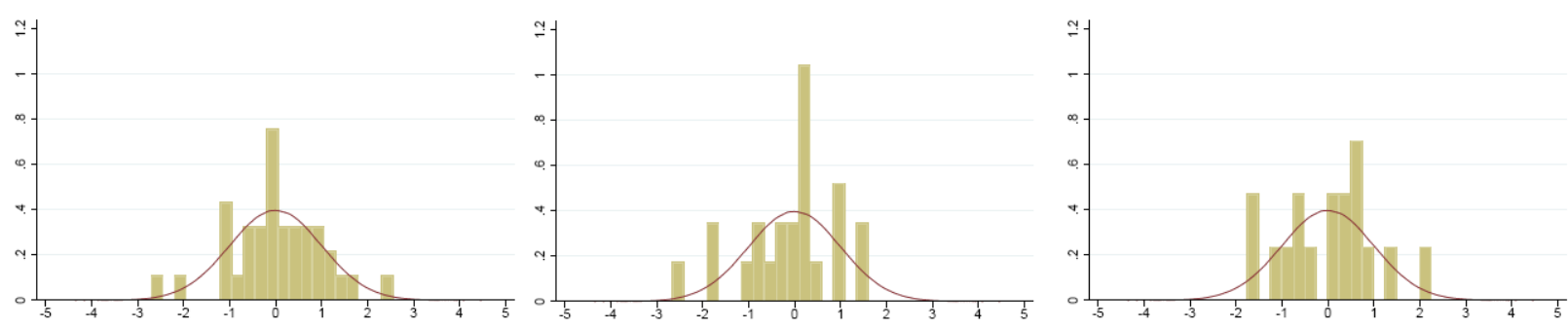

(B) Year-ahead forecast errors published year-end
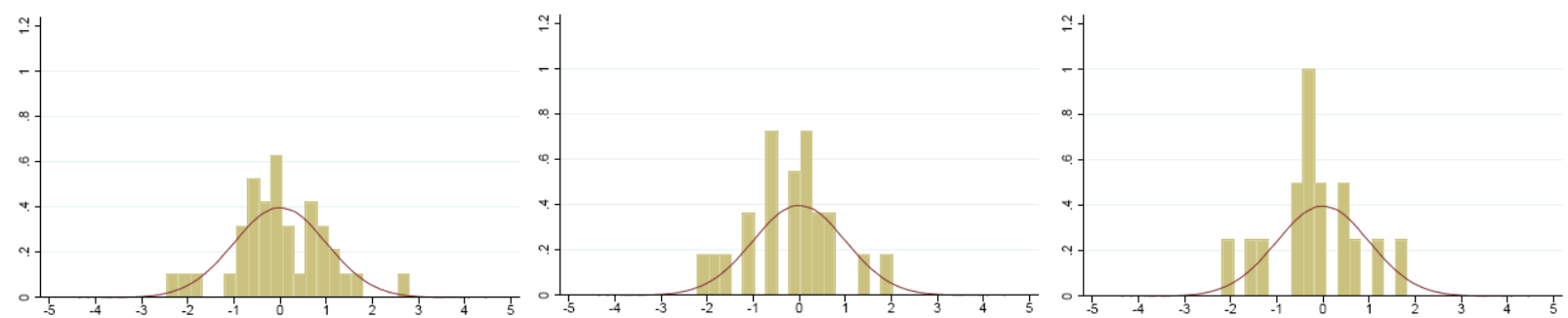

(C) Year-ahead forecast errors published mid-year
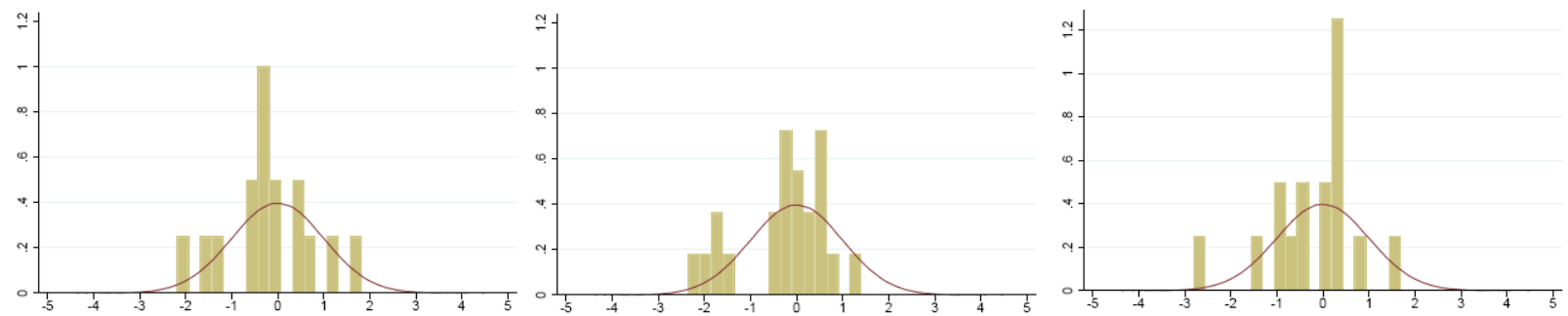

(D) Two-year ahead forecast errors published year-end
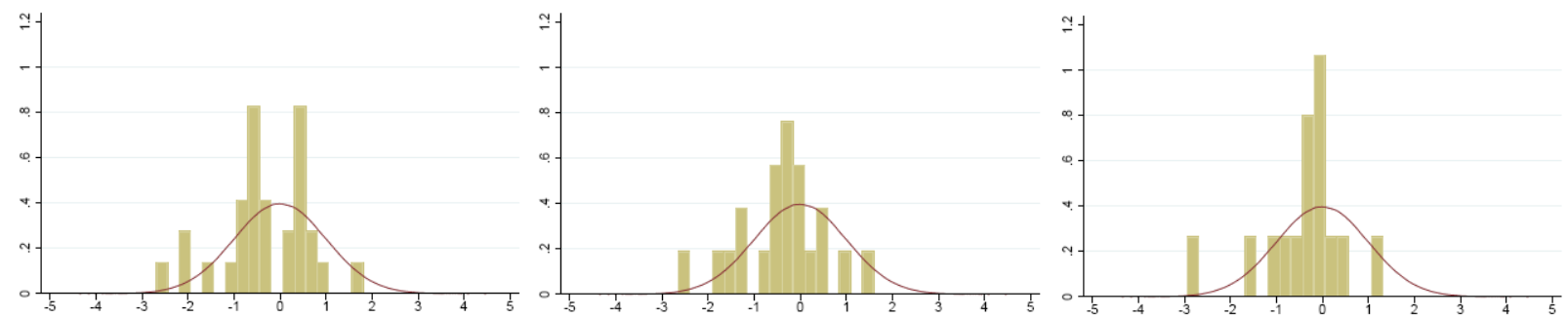

Note: These charts are designed to show whether forecast errors of GDP growth are normally distributed and unbiased at different forecast horizons. The null hypothesis is that forecast errors are normally distributed with zero mean but with a variance which varies for each organisation and across each forecast horizon. To represent this, forecast errors for each organisation and for each forecast horizon are normalised by their RMSE with the red curve showing the hypothetical frequency distribution of a standard normal variable, to which the histograms should converge under the null hypothesis.

OECD forecasts are for expenditure GDP for 1981, 1980-, 1982-, and 1989-2017 in panels (A), (B), (C) and (D). Similarly, RBNZ forecasts are for production GDP for 1995, 1996-, 1996- and 1997-2017 and Treasury forecasts are for production GDP for 2001, 2002-, 2002- and 2003-2017.

Source: New Zealand Treasury, OECD Economic Outlook databases, Reserve Bank of New Zealand, authors' calculations. 


\section{Figure 2. Largest absolute GDP forecast errors}

\section{(percentage points)}

(i) OECD (ii) RBNZ (iii) The Treasury

(A) Year-ahead forecast errors published year-end
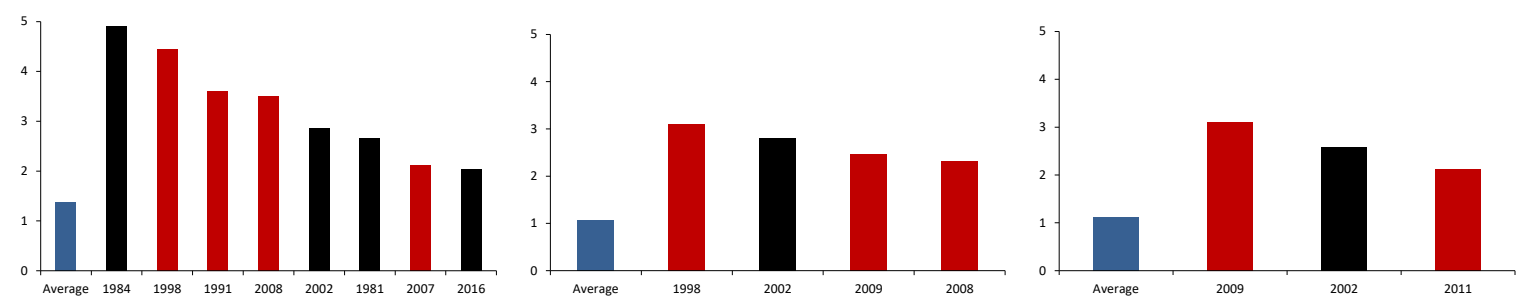

(B) Year-ahead forecast errors published mid-year

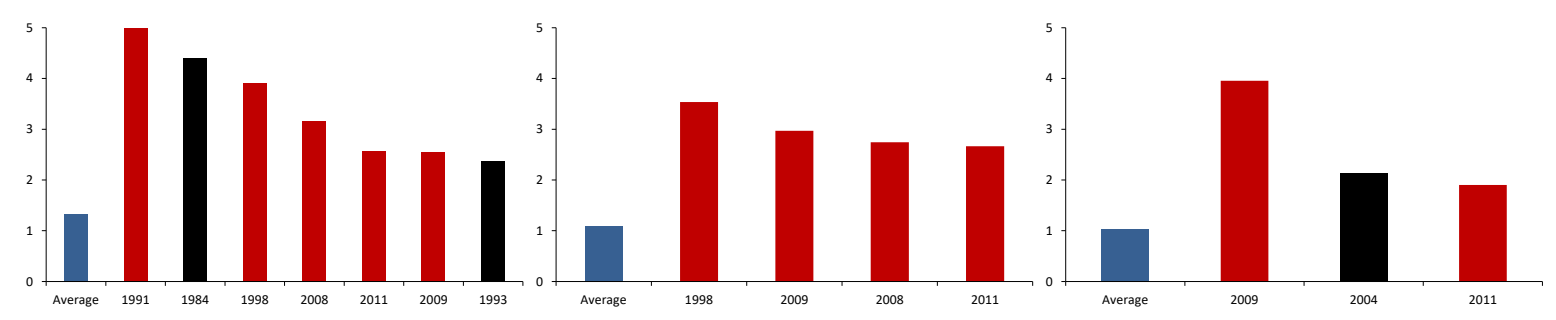

(C) Two-year ahead forecast errors published year-end
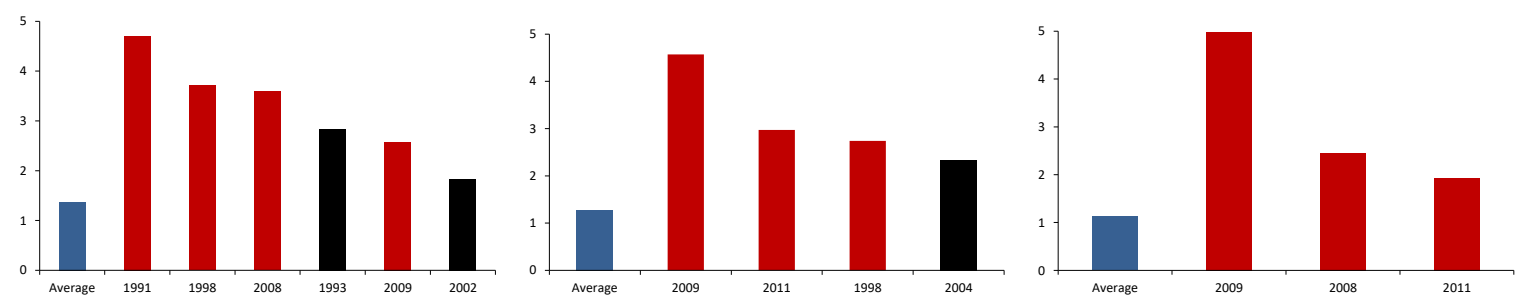

Note: Largest $20 \%$ of forecast errors over the period for which forecasts are available. Red bars correspond to over-predictions, black bars correspond to under-predictions. Forecasts from the OECD Spring Economic Outlook from 1986 to 2017, the RBNZ May or June Monetary Policy Statement from 1996 to 2017 and the Treasury Budget Economic and Fiscal Update from 2001 to 2017. The outturn for a particular year is defined as that published in the OECD Spring Economic Outlook in the year following the outturn.

OECD forecasts are for expenditure GDP for 1980-, 1982-, and 1989-2017 in panels (A), (B) and (C). Similarly, RBNZ forecast errors are for production GDP for 1996-, 1996- and 1997-2017 and Treasury forecasts are for production GDP for 2002-, 2002- and 2003-2017.

Source: New Zealand Treasury, OECD Economic Outlook databases, Reserve Bank of New Zealand, authors' calculations. 
Table 1. Descriptive statistics for GDP forecast errors

(percentage points, unless otherwise specified) ${ }^{1}$

(A) Year-ahead forecast errors published year-end

\begin{tabular}{lcccccc}
\hline & Mean error & $\begin{array}{c}\text { Mean absolute } \\
\text { error }\end{array}$ & RMSE & $\begin{array}{r}\%+\text { ve errors } \\
>2 \times \text { RMSE }\end{array}$ & $\begin{array}{r}\% \text {-ve errors } \\
>2 \times \text { RMSE }\end{array}$ & Normality test $^{1}$ \\
\cline { 2 - 3 } & 0.0 & 1.2 & 1.8 & $0 \%$ & $3 \%$ & Not reject \\
$\begin{array}{l}\text { RBNZ } \\
(1996-2017)\end{array}$ & -0.3 & 1.1 & 1.4 & $5 \%$ & $5 \%$ & Not reject \\
$\begin{array}{l}\text { The Treasury } \\
(2002-17)\end{array}$ & -0.3 & 1.1 & 1.4 & $0 \%$ & $6 \%$ & Not reject \\
\hline
\end{tabular}

(B) Year-ahead forecast errors published mid-year

\begin{tabular}{lcccccc}
\hline & Mean error & $\begin{array}{c}\text { Mean absolute } \\
\text { error }\end{array}$ & RMSE & $\begin{array}{r}\%+\text { ve errors } \\
>2 \times \text { RMSE }\end{array}$ & $\begin{array}{r}\% \text {-ve errors } \\
>2 \times \text { RMSE }\end{array}$ & Normality test $^{1}$ \\
\cline { 2 - 3 } & -0.4 & 1.3 & 1.8 & $3 \%$ & $7 \%$ & Not reject \\
$(1982-2017)$ & -0.5 & 1.1 & 1.5 & $0 \%$ & $5 \%$ & Not reject \\
$\begin{array}{l}\text { RBNZ } \\
(1996-2017)\end{array}$ & -0.3 & 1.0 & 1.4 & $0 \%$ & $6 \%$ & Not reject \\
$\begin{array}{l}\text { The Treasury } \\
(2002-17)\end{array}$ & & & & &
\end{tabular}

(C) Two-year-ahead forecast errors published year-end

\begin{tabular}{|c|c|c|c|c|c|c|}
\hline & Mean error & $\begin{array}{c}\text { Mean absolute } \\
\text { error }\end{array}$ & RMSE & $\begin{array}{c}\%+\text { ve errors } \\
>2 \times \text { RMSE }\end{array}$ & $\begin{array}{l}\% \text {-ve errors } \\
>2 \times \text { RMSE }\end{array}$ & Normality test ${ }^{1}$ \\
\hline $\begin{array}{l}\text { OECD } \\
(1989-2017)\end{array}$ & -0.5 & 1.4 & 1.7 & $0 \%$ & $10 \%$ & Not reject \\
\hline $\begin{array}{l}\text { RBNZ } \\
(1997-2017)\end{array}$ & -0.7 & 1.3 & 1.7 & $0 \%$ & $5 \%$ & Not reject \\
\hline $\begin{array}{l}\text { The Treasury } \\
(2003-17)\end{array}$ & -0.7 & 1.1 & 1.7 & $0 \%$ & $7 \%$ & Not reject \\
\hline
\end{tabular}

Source: New Zealand Treasury, OECD Economic Outlook databases, Reserve Bank of New Zealand, authors' calculations.

Note: Jarque-Bera normality test. OECD forecasts are for expenditure GDP while RBNZ and Treasury forecasts are for production GDP.

1) For a comparison of the three organisations over comparable time periods see Annex A. 


\section{A probit approach to quantifying downturn risks}

11. To identify the risk of a downturn this paper follows the methodology used in Turner et al. (2018), which uses a probit model to assess the probability of a future downturn. The dependent variable in the probit regression takes the value one if that quarter is part of a severe downturn episode and zero otherwise. A severe downturn episode is defined as a series of quarters in which GDP per capita falls in both the initial and final quarter of the episode and the cumulative fall in GDP per capita is at least 2 percentage points over the entire episode.

12. Separate probit models are estimated to assess the risk of a future downturn at horizons of two, four, six and eight quarters ahead. A range of both domestic and international macroeconomic and financial market variables are tested for significance in each of the probit models. These variables are based on those found to be the most reliable in predicting future severe downturns at horizons of up to eight quarters across OECD economies in previous OECD work (Hermansen and Röhn, 2016). Domestic variables tested include the slope of the yield curve, unemployment and growth in credit and real house prices. International variables tested include growth in OECD-wide credit and real house prices. Some variables may be more relevant for predicting downturns at shorter horizons, such as a sharp decline in the unemployment rate, while other variables may be more relevant at longer horizons, such as a gradual build-up in credit growth over the past three years. As such, different variables are included at different horizons.

\section{Illustration for New Zealand}

13. This paper investigates probit models for New Zealand estimated over 1988 to 2018Q3. Arguably, the sample period should start around 1993, which would exclude the structural changes and economic volatility in the New Zealand economy following the major reforms that occurred from 1984 to 1992 (OECD, 1994, OECD, 1996). Over this period New Zealand went from being one of the most regulated economies in the OECD to arguably the least regulated (Brash, 1996). However, a sample period this short would not capture a sufficient number of downturn episodes to estimate the probit models. As such, a trade-off is made to capture additional downturn episodes while starting as close to the post-reform period as possible. This sample period also approximately separates the period before and after inflation targeting in New Zealand, which began in $1990 .^{8}$

14. Four downturn episodes are identified since 1988 (Table 2). The most recent literature on classical recessions in New Zealand on data released up to 2014Q3 suggests that three of these four downturn episodes overlap with the last four classical recessions in New Zealand (Hall and McDermott, 2016). However, since this paper was published data revisions have altered the profile of GDP growth in the late 1980s and increased the decline in GDP in 2010Q3 and Q4.

\footnotetext{
${ }^{8}$ For a brief history of and changes to inflation targeting in New Zealand see Lewis and McDermott (2016).
} 
Table 2. Downturn episodes and classical recessions in New Zealand

\begin{tabular}{c|c|c}
\hline Downturn episodes & $\begin{array}{c}\text { Classical recessions } \\
\text { (Hall and McDermott (2016)) }\end{array}$ & $\begin{array}{c}\text { Additional 'technical' recessions } \\
\text { (Hall and McDermott (2016)) }\end{array}$ \\
\hline 1989Q3-91Q2 & 1988Q1-88Q4 \& 1991Q1-Q2 & 1987Q4-1989Q4 \\
1997Q4-98Q2 & 1997Q3-98Q1 & - \\
2008Q1-09Q1 & 2008Q1-09Q1 & - \\
2010Q3-Q4 & - & 2010Q3-Q4 \\
\hline
\end{tabular}

Source: Hall and McDermott (2016), authors' calculations.

Note: A downturn episode is defined as a series of quarters in which GDP per capita falls in both the initial and final quarter of the episode and GDP per capita falls cumulatively by at least 2 percentage points.

Hall and McDermott (2016) determine classical recessions using the Bry-Broshan (BB) dating algorithm, which looks for turning points in a smoothed seasonally-adjusted series to ensure that erratic movements are not misleading. They determine technical recessions using the BBQ dating algorithm of Harding and Pagan (2006), which ignores the smoothing element, given that the benefit of smoothing is 'much reduced' if dating is done with quarterly data. The authors prefer the BB algorithm approach, largely due to the explanation of the differences between the two methods: there was likely volatility following the introduction of a goods and services (value-added) tax in 1986 and the classification of the recession in 2010 is a relatively marginal call.

15. The first three downturn episodes were triggered by international events but exacerbated by domestic pressures and imbalances. As discussed in Reddell and Sleeman (2008), the RBNZ Monetary Policy Statement from March 2011 and the New Zealand Treasury Budget Economic and Fiscal Update from May 2011, the main drivers of these downturn episodes include:

- 1989-91 downturn: Wide-ranging deregulation of the financial sector implemented in 1984/85 was followed by significant credit growth, financing speculation in the share market and property market. In October 1987 the global share market crashed, resulting in increasingly constrained access to credit over coming years. Domestic fiscal spending contracted sharply in late 1990 and the global economy entered a recession in $1991 .^{9}$

- 1997/98 downturn: The Asian financial crisis began in July 1997, significantly reducing New Zealand's exports. At the time around one-third of New Zealand's exports and much of Australia's, New Zealand's largest trading partner, were destined for the region. In addition, New Zealand faced a severe drought in 1997/98, substantially reducing agricultural output, with flow-on effects through the rest of the economy.

- 2008/09 downturn: The global financial crisis began in 2008, reducing export revenues and lowering consumer and business confidence, with negative flow-on effects to investment and employment.

- 2010 downturn: Both households and businesses were cautious in their spending and investment, increasing savings and strengthening their financial positions. The elevated New Zealand dollar limited growth in the tradables sector. Businesses increased employment only modestly and growth in government spending was weak. Agricultural production slowed sharply toward the end of 2010 due to an early summer drought.

\footnotetext{
${ }^{9}$ For more information on the global recession see Box 1.1 in the IMF April 2009 World Economic Outlook.
} 
16. Excluding the 1997/98 downturn from the probit model greatly increases the significance of the estimated coefficients and the percentage of correct predictions (Table A3 and Table 3). In particular, this exclusion results in the coefficients for both domestic and OECD credit growth in the four-, six-, and eight-quarter horizon specifications becoming significant. As such, the 1997/98 downturn is excluded from the following probit models. This downturn appeared to be driven by idiosyncratic 'one-off' factors - the Asian financial crisis and a drought in New Zealand. The ultimate goal of this exercise is to use a small number of high-level indicators to estimate the probability of a future downturn several quarters in advance, rather than provide a detailed explanation for all historical downturns. Including specific variables to account for the idiosyncratic nature of the 1997/98 episode would not necessarily be a useful predictor of future downturns. However, this event does indicate the vulnerability of the New Zealand economy to one-off shocks, such as weather patterns and developments in non-OECD economies. One argument for including this downturn in the model is that the resulting lack of statistical significance of the coefficients of the probit model illustrates the limitations on predicting downturns in New Zealand due to the country's vulnerability to unforecastable events. This paper seeks to illustrate the extent to which downturns can be predicted while highlighting the many caveats to these models, including the difficulty in forecasting one-off events.

Table 3. Percentage of correct predictions

\begin{tabular}{|c|c|c|c|c|}
\hline & \multicolumn{4}{|c|}{ Probit regression at horizon of Q quarters } \\
\hline & $\mathrm{Q}=2$ & $\mathrm{Q}=4$ & $\mathrm{Q}=6$ & $\mathrm{Q}=8$ \\
\hline & 1980Q3-2018Q3 & 1981-2018Q3 & 1981Q3-2018Q3 & 1982-2018Q3 \\
\hline & \multicolumn{4}{|c|}{ Excluding 1997/98 } \\
\hline$\%$ of correct predictions ${ }^{1}$ & $88 \%$ & $94 \%$ & $88 \%$ & $90 \%$ \\
\hline Downturns & $95 \%$ & $100 \%$ & $95 \%$ & $95 \%$ \\
\hline \multirow[t]{2}{*}{ Non-downturns } & $86 \%$ & $93 \%$ & $87 \%$ & $88 \%$ \\
\hline & \multicolumn{4}{|c|}{ Including 1997/98 } \\
\hline$\%$ of correct predictions ${ }^{1}$ & $81 \%$ & $78 \%$ & $71 \%$ & $73 \%$ \\
\hline Downturns & $91 \%$ & $87 \%$ & $87 \%$ & $87 \%$ \\
\hline Non-downturns & $79 \%$ & $76 \%$ & $67 \%$ & $69 \%$ \\
\hline
\end{tabular}

17. Several macroeconomic and financial variables are found to be associated with an increased risk of a downturn (Table 4). Different variables are found to be significant for each of the four horizons. These variables are:

- A negatively sloped yield curve in the two-quarter horizon specification, consistent with a maturing of the business cycle and a (possibly sharp) increase in policy rates, which may imply an imminent downturn. ${ }^{10}$

\footnotetext{
${ }^{10}$ For further details see Estrella and Mishkin (1997); Estrella (2007); Estrella et al. (2003); Dovern and Ziegler (2008); Fornari and Lenke (2010).
} 
- An increase in unemployment over the previous year in the two-, four- and six-quarter horizon specifications, signalling the beginning of a deterioration in economic activity.

- Inflation above the midpoint of the RBNZ's inflation target in the eight-quarter horizon specification, highlighting the risk that high inflation may lead to a tightening of monetary policy.

- Rapid, sustained growth in the New Zealand credit-GDP ratio over the previous three years in the four-, six- and eight-quarter horizon specifications, signalling the possible build-up of financial imbalances.

- Rapid, sustained growth in the OECD credit-GDP ratio over the previous three years in all specifications, suggesting potential international financial spillovers due to financial imbalances.

- Rapid, sustained growth in OECD real house prices over the previous three years in the four-, six- and eight-quarter horizon specifications, suggesting potential international spillovers due to financial imbalances.

18. Several variables were not found to be associated with an increased risk of a downturn at various horizons. These variables include:

- Growth in New Zealand's total exports and dairy exports (which made up 26\% of New Zealand's total exports in 2017). This lack of association is thought to be due to the contemporaneous relationship between a decline in exports and economic activity, making exports a poor early warning indicator.

- Growth in New Zealand house prices over the previous one and three years across all horizons. This lack of association is likely due to a high degree of correlation with the New Zealand credit-GDP ratio.

19. Other variables may have been useful to include, such as a variable reflecting developments in Australia or Asia, New Zealand's largest trading partners. Australian variables are highly correlated with their equivalents in New Zealand, suggesting that these developments may have already been captured in domestic variables. In addition, Australia has not experienced a downturn since 1991, potentially limiting the ability of Australian variables to predict downturns in New Zealand. Asian economies, especially China, have relatively recently grown in importance to New Zealand when looking across a 30-year horizon, which means that the coefficients on these variables are unlikely to be stable over the entire sample. 
Table 4. Probit regressions of a severe downturn in NZ at different horizons

\begin{tabular}{|c|c|c|c|c|c|}
\hline \multirow{3}{*}{ 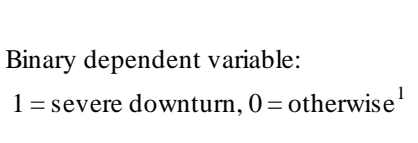 } & \multirow{3}{*}{$\begin{array}{l}\text { Standard } \\
\text { deviation }\end{array}$} & \multicolumn{4}{|c|}{ Probit regression at horizon of Q quarters } \\
\hline & & $\mathrm{Q}=2$ & $\mathrm{Q}=4$ & $\mathrm{Q}=6$ & $\mathrm{Q}=8$ \\
\hline & & 1988-2018Q3 & 1988-2018Q3 & 1988-2018Q3 & 1989Q3-2018Q3 \\
\hline Constant & & $-3.73 * * *$ & $-14.10 * * *$ & $-8.33 * * *$ & $-7.62 * * *$ \\
\hline Yield curve slope ${ }^{2}$ & 1.50 & $-0.31 * *$ & & & \\
\hline Unemployment rate & & & & & \\
\hline 1-year change & 1.01 & $0.59 * * *$ & $1.66^{* *}$ & $0.87 * * *$ & \\
\hline CPI inflation & & & & & \\
\hline Difference from target midpoint ${ }^{3}$ & 1.83 & & & & $0.74 * *$ \\
\hline Private credit-to-GDP ratio ${ }^{4}$ & & & & & \\
\hline 3-year annual average change & 3.10 & & $0.36^{*}$ & $0.24 * *$ & $0.17 * *$ \\
\hline OECD private credit-to-GDP ratio ${ }^{5}$ & & & & & \\
\hline 3-year annual average change & 1.80 & $0.88 * * *$ & $2.25 * * *$ & $1.23 * * *$ & $0.91 * *$ \\
\hline OECD real house prices & & & & & \\
\hline 3-year annual change & 2.65 & & $1.09 * * *$ & $0.77 * * *$ & $0.77 * * *$ \\
\hline McFadden R-sqd & & 0.54 & 0.77 & 0.64 & 0.63 \\
\hline$\%$ of correct predictions ${ }^{6}$ & & $88 \%$ & $94 \%$ & $88 \%$ & $90 \%$ \\
\hline Downturns & & $95 \%$ & $100 \%$ & $95 \%$ & $95 \%$ \\
\hline Non-downturns & & $86 \%$ & $93 \%$ & $87 \%$ & $88 \%$ \\
\hline
\end{tabular}

Notes:

1) A severe downturn episode is defined as a series of quarters in which GDP per capita falls in both the initial and final quarter of the episode and GDP per capita falls cumulatively by at least 2 percentage points.

2) The yield curve slope is defined as the interest rate on 10-year government bonds less the short-term policy rate.

3) The midpoint of the Reserve Bank of New Zealand target band is assumed from 1990 onwards. For the pre-inflation-targeting period from 1980-1990, the target midpoint in 1990 of $4 \%$ is assumed as the midpoint.

4) Credit to the private, non-financial sector from banks.

5) Credit to the private, non-financial sector from all sectors.

6) Predictions categorised according to a $15 \%$ probability threshold.

Statistical significance of coefficients at the $1 \%, 5 \%$ and $10 \%$ levels are denoted by '***', '**' and '*”.

For the probit regression at an horizon of $\mathrm{Q}$ quarters $(\mathrm{Q}=2,4,6$ or 8$)$, explanatory variables enter the equations at different horizons due to the timing of data releases. The yield curve variable is lagged by Q-1 quarters, unemployment and CPI variables are lagged by Q quarters, house price variables are lagged by $Q+1$ quarters, while credit variables are lagged by $Q+2$ quarters.

Source: OECD Analytical Database and OECD Resilience Database. 


\section{Linking quarterly probit probabilities to annual downturn risks}

20. GDP forecasts are commonly discussed as annual average percent changes, as such, the remainder of the analysis has been undertaken on an annual basis. To represent the risk around the annual GDP growth forecasts, it is first necessary to convert the quarterly probit probabilities of a downturn risk into the corresponding risk for an annual forecast.

21. The calculation of an annual risk measure, and in particular how it is related to the quarterly probit probabilities, depends on the forecast horizon (Figure 3). For example, consider a year-ahead forecast that is published mid-year i.e. towards the end of the second quarter in year $\mathrm{T}$, where it can be assumed that at the time of publication most data are available for the first quarter of year T (Figure 3, panel B). The risk of a downturn in year $\mathrm{T}+1$ is then calculated as a weighted average of the probit probabilities of a future downturn two, four and six quarters in advance. These quarters correspond to a weighted average of a downturn in the third quarter of year $\mathrm{T}$ (two quarters following the last quarter for which data is available) and the first and third quarters of year $(\mathrm{T}+1)$. The probabilities are given weights reflecting the importance of the quarterly growth rates in the calculation of annual growth of year $(\mathrm{T}+1)$ relative to year $\mathrm{T}$ (Cross and Wyman, 2011). Thus, in this case of the mid-year year-ahead forecast, the probability of a downturn in the first quarter of year $(\mathrm{T}+1)$ is given double the weight of the probabilities of a downturn in the third quarter of years $\mathrm{T}$ and $(\mathrm{T}+1)$. Annual probabilities can be calculated for the other forecast horizons in a similar fashion (Figure 5, panel A and C). 


\section{Figure 3. Relating quarterly probit probabilities to annual probabilities}

(A) Year-ahead forecast publis hed year-end:

Probability of a downturn, $\mathrm{P}^{\mathrm{A}, \mathrm{T}+1}=(2 / 3)^{*} \mathrm{p}_{2}+(1 / 3)^{*} \mathrm{p}_{4}$

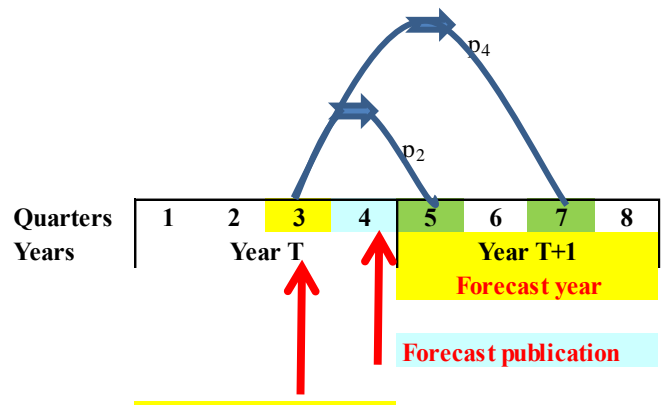

Ass ume data available

(B) Year-ahead forecast publis hed mid-year:

Probability of a downturn, $\mathrm{P}^{\mathrm{S}, \mathrm{T}+1}=0.25^{*} \mathrm{p}_{2}+0.5^{*} \mathrm{p}_{4}+0.25^{*} \mathrm{p}_{6}$

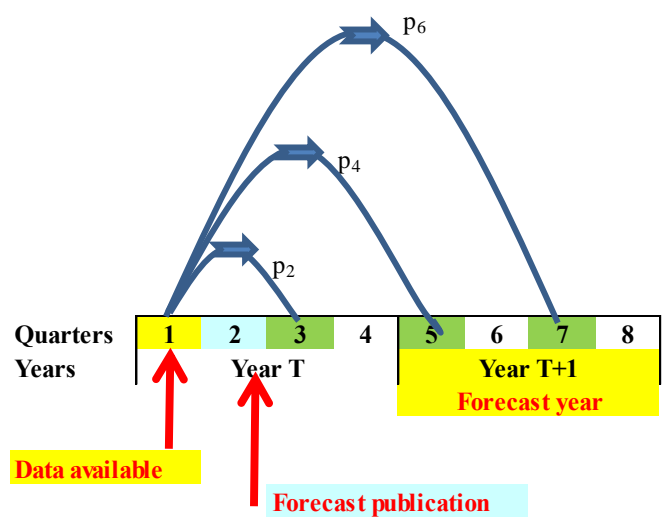

(C) Two-year-ahead forecast publis hed year-end:

Probability of a downturn, $\mathrm{P}^{\mathrm{A}, \mathrm{T}+2}=0.25^{*} \mathrm{p}_{4}+0.5^{*} \mathrm{p}_{6}+0.25^{*} \mathrm{p}_{8}$

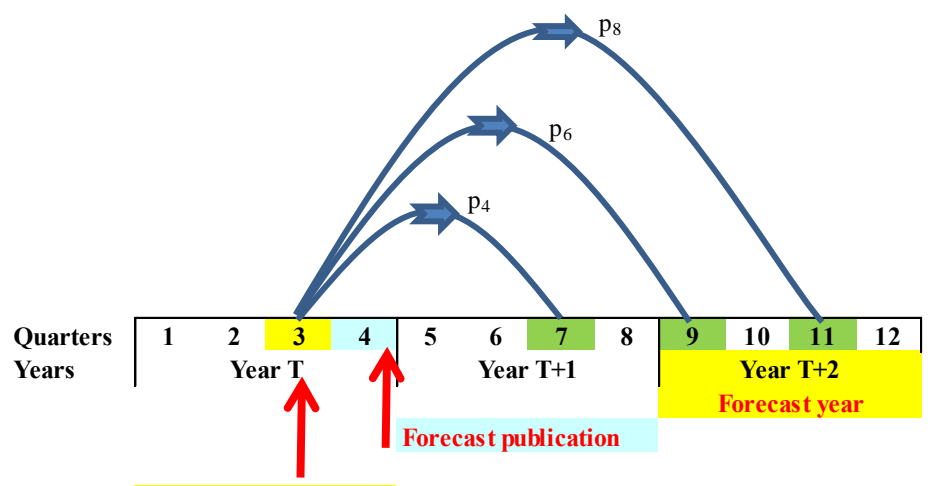

Assume data available

Note: The chart summarises how quarterly probit probabilities, $\mathrm{p}_{\mathrm{Q}}$, of a future downturn at an horizon of $\mathrm{Q}$ quarters $(\mathrm{Q}=2,4,6$ or 8$)$ are converted to an annual probability of a future downturn, $\mathrm{P}^{\mathrm{s}}, \mathrm{T}+\mathrm{i}$, where s represents whether the forecast is published in mid-year $(\mathrm{s}=\mathrm{M})$ or year-end $(\mathrm{s}=\mathrm{E})$ of year $\mathrm{T}$ and the forecast is for year $(\mathrm{T}+\mathrm{i})$, where the forecast horizon is $\mathrm{i}=1$ or 2 years. A mid-year (year-end) forecast is published towards the end of the second (fourth) quarter, so that most data for the quarterly probit model will be available up to the first (third) quarter. 
22. The probabilities of a downturn estimated by the probit models can be broken down into the contribution from each variable in the model (Figure 3). The breakdown of both quarterly and annual probabilities yields similar conclusions; as such for simplicity the breakdown is provided at an annual frequency. Across each horizon the two OECD variables, credit-GDP ratio and real house prices, are the main contributors to the probability of a downturn. The other domestic variables contribute at the margin. At the shortest horizon, the current-year forecast published mid-year, the slope of the yield curve increases the risk of a downturn (Figure 3, Panel A). For the three other horizons, the growth of domestic credit significantly raises the downturn risk (Figure 3, Panels B, C and D).

23. From a purely statistical point of view the models give some 'false alarms' of a potential downturn, which for the purpose of this paper is an annual probability of a downturn greater than $10 \%$ (Figure 4). However, the majority of these false alarms occur before or after downturn episodes, for example before and after the downturn in 1989-91, in 2007 excluding at the mid-year current-year horizon and in 2011 at the year-end two-year ahead horizon. As such, these false alarms may not significantly detract from the usefulness of the model as they may provide information to policymakers on the increased likelihood of a downturn. 


\section{Figure 4. Decomposition of downturn risks}

(Contributions unless otherwise stated)

(A) Current-year forecast published mid-year

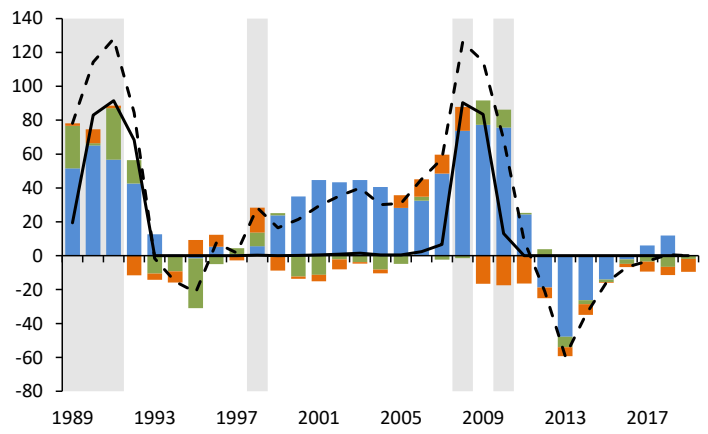

(C) Year-ahead forecast published year ahead

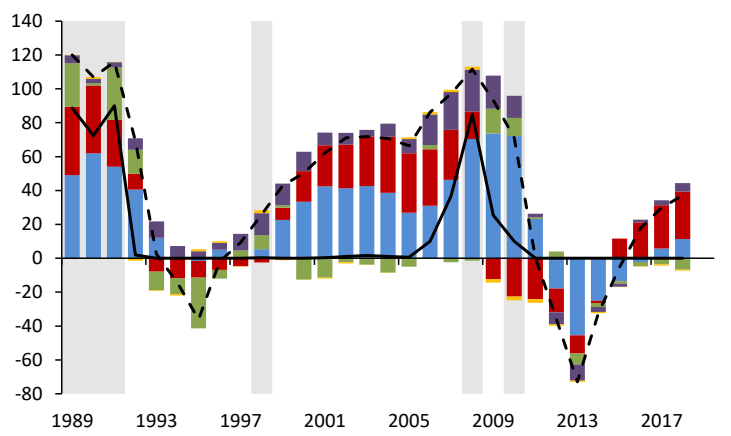

(B) Year-ahead forecast published year-end

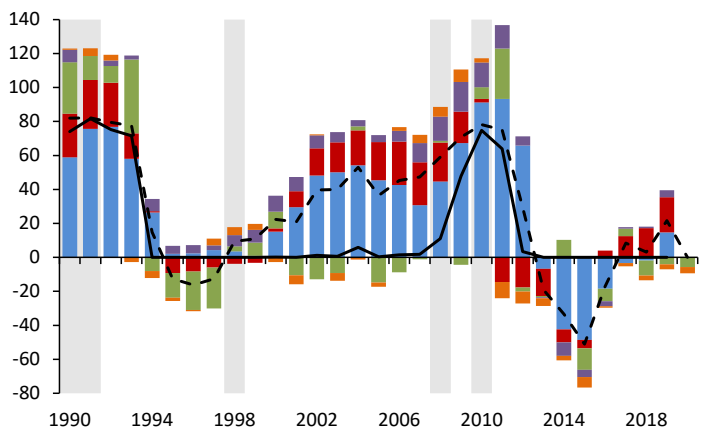

(D) Two-year ahead forecast published year-end

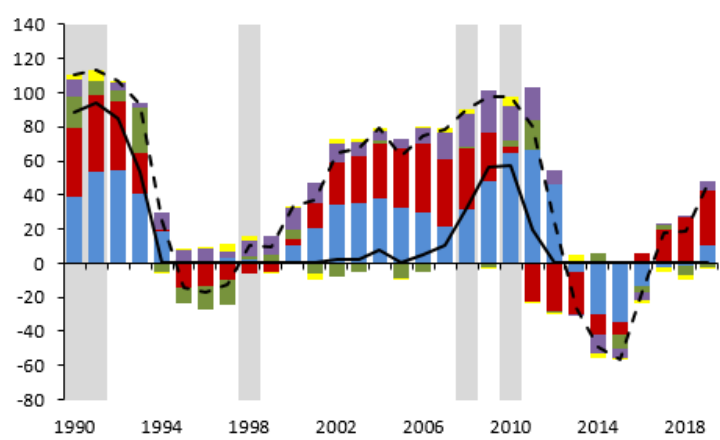

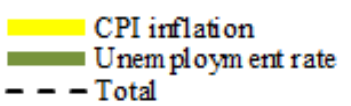

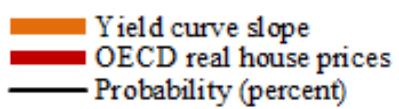

Credit-GDP ratio

OECD credit-GDP ratio

Note: The dashed black 'Total' line is the sum of the contributions of the bars but does not include the constant. This variable is a measure of the location of the likelihood on a normal distribution, which is transformed into the corresponding probability that a downturn occurs, as represented by the solid black 'Probability' line which takes a value between 0 and 1 . The grey shaded areas represent years in which at least two quarters of the year are identified as downturn episodes. A downturn episode is defined as a series of quarters in which GDP per capita falls in both the initial and final quarter of the episode and GDP per capita falls cumulatively by at least 2 percentage points. The $\mathrm{x}$-axis describes the period for which the forecast is made. For example for the midyear year-ahead forecast the probability of a downturn in 2009 is a weighted average of the probability of a downturn in 2008Q3, 2009Q1 and 2009Q3, as outlined in Section 4. 
Figure 5. Predicted probability of a downturn

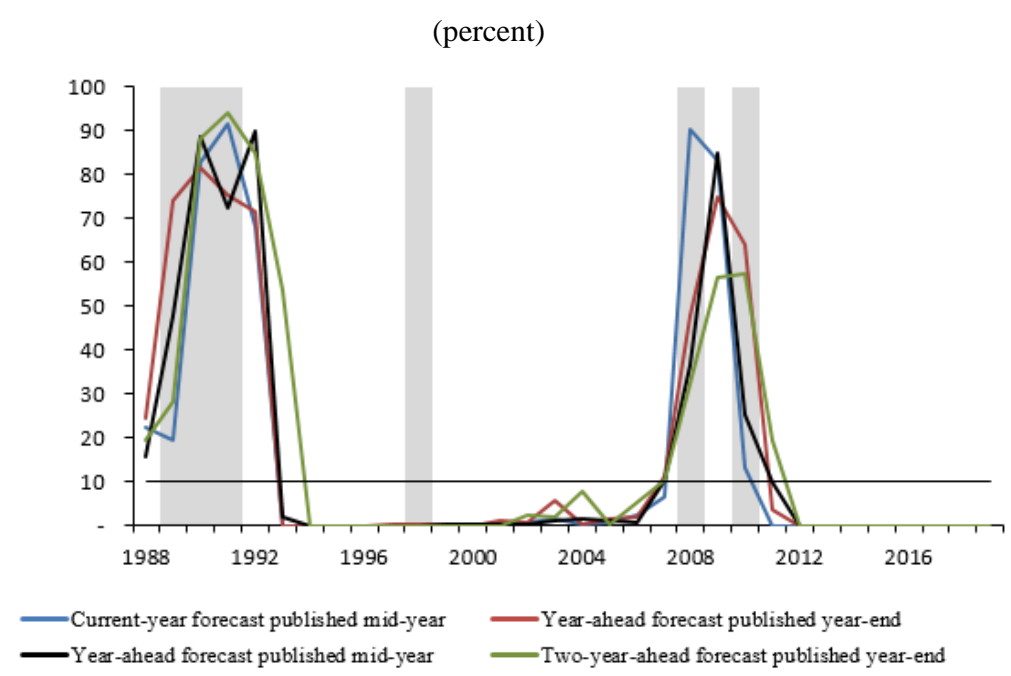

Source: Authors' calculations.

Note: The grey shaded areas represent years in which at least two quarters of the year are identified as downturn episodes. A downturn episode is defined as a series of quarters in which GDP per capita falls in both the initial and final quarter of the episode and GDP per capita falls cumulatively by at least 2 percentage points. The $\mathrm{x}$ axis describes the period for which the forecast is made. For example for the mid-year year-ahead forecast the probability of a downturn in 2009 is a weighted average of the probability of a downturn in 2008Q3, 2009Q1 and 2009Q3, as outlined in Section 4.

\section{Fan charts}

\subsection{A brief history of the use of fan charts}

24. While the Bank of England (Britton et al., 1997; Bank of England, 2005) and the Swedish Riksbank (Sveriges Riksbank, 2007) pioneered the use of fan charts in macroeconomic forecasting, this practice has since spread among many central banks as well as other major national and international institutions. ${ }^{11}$

25. In New Zealand, the RBNZ last used fan charts in the June 2014 Monetary Policy Statement to highlight the uncertainty around the outlook for inflation, interest rates and the output gap due to incorrectly assessing the size of the factors that drive the projection, only one of the many sources of uncertainty. These fan charts were produced using the RBNZ's forecasting model by simulating the effect of varying the important drivers of the economic outlook. ${ }^{12}$ In 2017 the RBNZ noted the usefulness of fan charts to show the extent of uncertainty but argued that publishing a range of potential scenarios to illustrate the sensitivity of forecasts to alternative economic developments is a more helpful method to communicate risks (McDermott, 2017).

\footnotetext{
${ }^{11}$ See World Bank (2016) for a recent survey.

12 The fans summarise a collection of 1,000 different scenarios resulting from different assumed outturns of the drivers of the New Zealand economy. The shocks to each driver in each scenario are selected from a normal distribution based on the standard deviations and correlations of the shocks identified by the forecasting model. For more detail, see the June 2014 Monetary Policy Statement.
} 
26. The Treasury has used fan charts that are parameterised on historical forecasts to describe uncertainty associated with its forecasts for tax revenue since 2010 (Treasury, 2016). Forecast errors in the future are assumed to have a zero mean and are normally distributed, which results in symmetric fan charts (Parkyn, 2010). However, Parkyn notes that this assumption is a matter of judgement. Tax revenues were underestimated on average over the paper's sample period of 1994 to 2009, likely a result of the economy being in an expansion phase over the majority of this time. Nonetheless, the assumption of normality cannot be rejected at the 5\% significance level, likely due to a small number of data points, a problem also encountered in this analysis (see Section 1). Parkyn notes the helpfulness of more data, which will indicate if there is an opposite bias during a downturn and suggests that an alternative would be to subjectively apply skew to the fan chart distributions based on judgement of the current balance of risks.

27. The Treasury has also used fan charts to characterise uncertainty around GDP and other macroeconomic forecasts. In a Monthly Economic Indicators (MEI) special topic on illustrating forecast uncertainty, symmetric fan charts were used to convey uncertainty (Treasury, 2016).

\subsection{Designing fan charts to reflect downturn risks}

28. The approach to parameterise a fan chart in this paper is based on both past forecast errors and the risk of a future severe downturn derived from the quarterly probit models, which determines the skew of the fan chart.

29. If the risk of a future downturn is very low, so that the annual probability of a downturn is below a threshold value, here taken to be $5 \%$, it is assumed that the possible outcomes are normally distributed around the published forecast. The published forecast is assumed to be the modal outcome. Given the symmetry of the normal distribution, the model outcome is also the mean outcome. The dispersion of possible outcomes is based on the historical RMSE of forecast errors during periods in which the probit probability was below the threshold value, which will typically be smaller than the RMSE over the entire forecast track record.

30. If the risk of a downturn according to the probit model is significant (i.e. above the $5 \%$ threshold value), then possible outcomes are assumed to be skewed to the downside. The extent of the skew is related to the size of the downturn risk. In this case, forecast errors are assumed to follow a two-piece normal distribution. This distribution is parameterised using the historical relationship between downturn probabilities and past forecast errors, as described below.

31. The current paper follows Turner et al. (2018) in using the two-piece normal distribution to model the distribution of risks when they are skewed. ${ }^{13}$ The two-piece normal distribution can be summarised in terms of three parameters - the mode $(\mu)$ and two standard deviations $\left(\sigma_{1}\right.$ and $\left.\sigma_{2}\right)$. This distribution is formed by taking two halves of normal distributions with parameters $\left(\mu, \sigma_{1}\right)$ and $\left(\mu, \sigma_{2}\right)$, and scaling them so that the probability density functions have a common value at the mode. With $\sigma_{1}>\sigma_{2}$ the distribution will have

\footnotetext{
${ }^{13}$ The Bank of England also use the two-piece normal distribution for their Inflation Report, but the degree of skew is based on the judgement of the Monetary Policy Committee (Britton et al., 1997; Bank of England, 2005).
} 
negative skewness, and the relationship between the mean outcome, $\mu^{*}$, and mode is given by:

$\mu-\mu^{*}=\mathrm{k}\left(\sigma_{1}-\sigma_{2}\right)$, where $\mathrm{k}=(2 / \pi)^{1 / 2}$.

To estimate the three parameters of the two-piece normal distribution for the downturn-risk regime, the following assumptions are made:

- The published forecast is the modal outcome, $\mu$.

- The smaller standard deviation, $\sigma_{2}$, of the upper half of the distribution can be approximated by the RMSE of forecast errors in periods when there is deemed to be little risk of a downturn (i.e. when the probit probability of a downturn is less than 5\%). The reasoning is that if the future outcome exceeds the published forecast then there is little reason to expect the forecast error to be exceptional. As such, the forecast error can be evaluated by the past forecast performance during safe periods.

- The larger standard deviation, $\sigma_{1}$, of the lower half of the distribution is computed by first quantifying the historical relationship between the mean forecast error and the probit probability of a downturn. Any observed non-trivial probability of a downturn can be converted into a predicted mean forecast error, which then, given the assumptions for $\mu$ and $\sigma_{2}$ above can be used to determine $\sigma_{1}$ using equation (1).

32. The relationship between the mean forecast error and the probit probability of a downturn is estimated from a regression of historical annual forecast errors, $\epsilon_{t}^{s, T+i}$ distinguishing whether the associated forecasts were published in the mid-year $(\mathrm{s}=\mathrm{M})$ or year-end $(\mathrm{s}=\mathrm{E})$ of year $\mathrm{T}$ and for which year $(\mathrm{T}+\mathrm{i})$ the forecasts were made (where $\mathrm{i}=0,1$ or 2). Thus, separate regressions of the form of equation (2) are run for each of: the midyear current year forecast errors $\left(\epsilon_{t}^{S, T}\right)$; the mid-year year-ahead forecast errors $\left(\epsilon_{t}^{S, T+1}\right)$; the year-end year-ahead forecast errors; $\left(\epsilon_{t}^{A, T+1}\right)$; and the year-end two-year-ahead forecast error $\left(\epsilon_{t}^{A, T+2}\right)$. Thus, regressions take the following form:

$\epsilon_{t}^{s, T+i}=\beta_{0}+\beta_{1} P_{t}^{s, T+i}$,

where $P_{T}^{s, T+i}$ is the corresponding annualised probability of a downturn derived from the quarterly probit model probabilities (see Section 3 ). In all cases, care is taken to ensure that data used to assess the future downturn probability would have been available at the time the forecast was published. ${ }^{14}$

\subsection{An illustration of fan charts for New Zealand}

33. The methodology to designing fan charts to reflect downturn risks described above is applied to New Zealand. Forecast errors from the OECD, the RBNZ and the Treasury are each separately regressed on the corresponding probability of a downturn in the period being forecast derived from the shorter-sample probit model. Separate regressions are run

\footnotetext{
14 Two further details of how the fan charts are constructed are discussed in Annex B of Turner et al. (2018), namely: the use of highest density intervals rather central prediction intervals; and the number of prediction intervals that are distinguished. Both are important in determining the appearance of the fan chart, but neither is central to the main argument about the importance of distinguishing downturn risks.
} 
for mid-year and year-end forecasts to reflect the different information available at each of these publication dates and the different weights applied to the quarterly forecasts when aggregated into an annual forecast.

34. The 1998 year is excluded from the analysis, as outlined in Section 3.1. As such, a dummy variable is included for 1998 which accounts for the large over-prediction forecast error that occurred for this year.

35. The sample period of these regressions differs for each organisation, which means that these results are not directly comparable across organisations. Results over comparable sample periods are included in Annex A (Table A4).

36. The main results from the regressions of forecast errors on the probit probabilities of a downturn are as follows:

- The estimated coefficients $\left(\beta_{1}\right)$ on the downturn probability are statistically significant, large and negative across most forecast horizons for all three organisations (Table 5). These negative coefficients imply that an increased risk of a downturn is strongly associated with forecast over-predictions. For example, a $50 \%$ probability of a downturn is associated with over-predictions of between 0.7 and 1.2 percentage points for the OECD, 1.8 to 2.9 percentage points for the RBNZ and 1.6 to 3.0 percentage points for the Treasury depending on the forecast horizon. The exceptions are the midyear current-year forecast for both the RBNZ and the Treasury, where there is little correlation between forecast errors and the probability of a downturn so that $\beta_{1}$ is insignificant. This result is consistent with the finding for OECD countries outlined in Section 1 that current-year forecasts are unbiased, with errors that are normally distributed (Turner et al., 2018). This result is perhaps not surprising, given that some information on the first two quarters of the current year is already available and that these first two quarters represent a substantial weight in the annual growth outcome for the current year.

- Across all forecast horizons the intercept term $\left(\beta_{0}\right)$ is always small and statistically insignificant, suggesting that when the probability of a future downturn is negligible then forecasts are unbiased.

- The dummy variable for 1998 is always statistically significant in the OECD and RBNZ regressions (and not included in the regressions for the Treasury, which start post-1998). 
Table 5. Regressions of forecast errors for New Zealand on downturn probabilities

(A) OECD

\begin{tabular}{|c|c|c|c|c|}
\hline \multirow{3}{*}{$\begin{array}{l}\text { Forecast published in } \\
\text { Forecast horizon } \\
\text { Sample period }\end{array}$} & \multicolumn{4}{|c|}{ Dependent variable: forecast error, $\epsilon_{t}{ }^{(s, t+i)}$} \\
\hline & $\begin{array}{c}\text { Mid-year } \\
\text { current-year }\end{array}$ & $\begin{array}{c}\text { Year-end } \\
\text { year-ahead }\end{array}$ & $\begin{array}{c}\text { Mid-year } \\
\text { year-ahead }\end{array}$ & $\begin{array}{c}\text { Year-end } \\
\text { 2-years-ahead }\end{array}$ \\
\hline & $1988-2017$ & $1989-2017$ & $1989-2017$ & $1991-2017$ \\
\hline \multirow{2}{*}{ Intercept term $\left(\beta_{0}\right)$} & 0.23 & 0.25 & -0.07 & -0.02 \\
\hline & - & - & - & - \\
\hline \multirow[t]{2}{*}{ Downturn probability $\mathrm{P}_{\mathrm{t}}^{(\mathrm{s}, \mathrm{t+ \textrm {i }})},\left(\beta_{1}\right)$} & -1.31 & -2.02 & -2.37 & -2.14 \\
\hline & * & $* *$ & $* *$ & $* *$ \\
\hline \multirow[t]{2}{*}{ Dummy for 1998} & -4.06 & -4.69 & -3.85 & -3.69 \\
\hline & $* * *$ & $* * *$ & $* *$ & $* *$ \\
\hline R-sqd adjusted & 0.36 & 0.35 & 0.31 & 0.27 \\
\hline
\end{tabular}

(B) RBNZ

\begin{tabular}{|c|c|c|c|c|}
\hline \multirow{3}{*}{$\begin{array}{l}\text { Forecast published in } \\
\text { Forecast horizon } \\
\text { Sample period } \\
\end{array}$} & \multicolumn{4}{|c|}{ Dependent variable: forecast error, $\epsilon_{t}{ }^{(s, t+i)}$} \\
\hline & $\begin{array}{c}\text { Mid-year } \\
\text { current-year }\end{array}$ & $\begin{array}{c}\text { Year-end } \\
\text { year-ahead }\end{array}$ & $\begin{array}{c}\text { Mid-year } \\
\text { year-ahead }\end{array}$ & $\begin{array}{c}\text { Year-end } \\
\text { 2-years-ahead }\end{array}$ \\
\hline & $1995-2017$ & $1996-2017$ & $1996-2017$ & $1997-2017$ \\
\hline \multirow[t]{2}{*}{ Intercept term $\left(\beta_{0}\right)$} & 0.09 & 0.24 & -0.01 & -0.06 \\
\hline & - & - & - & - \\
\hline \multirow[t]{2}{*}{ Downturn probability $\mathrm{P}_{\mathrm{t}}^{(\mathrm{s}, \mathrm{t}+\mathrm{i})},\left(\beta_{1}\right)$} & -0.63 & -3.59 & -4.13 & -5.79 \\
\hline & - & $* * *$ & $* * *$ & $* * *$ \\
\hline \multirow[t]{2}{*}{ Dummy for 1998} & -2.48 & -3.34 & -3.53 & -2.68 \\
\hline & $* * *$ & $* * *$ & $* * *$ & $* *$ \\
\hline \multirow[t]{3}{*}{$\underline{\text { R-sqd adjusted }}$} & 0.33 & 0.52 & 0.52 & 0.49 \\
\hline & \multicolumn{4}{|c|}{ (C) The Treasury } \\
\hline & \multicolumn{4}{|c|}{ Dependent variable: forecast error, $\epsilon_{t}{ }^{(s, t+i)}$} \\
\hline \multirow{2}{*}{$\begin{array}{l}\text { Forecast published in } \\
\text { Forecast horizon } \\
\text { Sample period } \\
\end{array}$} & $\begin{array}{c}\text { Mid-year } \\
\text { current-year }\end{array}$ & $\begin{array}{c}\text { Year-end } \\
\text { year-ahead } \\
\end{array}$ & $\begin{array}{c}\text { Mid-year } \\
\text { year-ahead }\end{array}$ & $\begin{array}{c}\text { Year-end } \\
\text { 2-years-ahead } \\
\end{array}$ \\
\hline & $2001-2017$ & $2002-2017$ & $2002-2017$ & 2003-2017 \\
\hline \multirow[t]{2}{*}{ Intercept term $\left(\beta_{0}\right)$} & 0.12 & 0.17 & 0.15 & 0.05 \\
\hline & - & - & - & - \\
\hline \multirow[t]{2}{*}{ Downturn probability $\mathrm{P}_{\mathrm{t}}^{(\mathrm{s}, \mathrm{t}+\mathrm{i})},\left(\beta_{1}\right)$} & -0.84 & -3.14 & -4.43 & -5.97 \\
\hline & - & $* *$ & $* *$ & $* * *$ \\
\hline$\underline{\text { R-sqd adjusted }}$ & 0.08 & 0.29 & 0.50 & 0.57 \\
\hline
\end{tabular}

Note: Statistical significance of coefficients at the $1 \%, 5 \%$ and $10 \%$ levels are denoted by '***', '**' and '*”'.

Source: New Zealand Treasury, OECD Economic Outlook databases, Reserve Bank of New Zealand, authors' calculations. 


\subsection{Fan charts for the mid-year 2018 Economic Outlook}

37. The fan charts calculated are computed based on the historical forecast errors by the OECD. While not shown, the fan charts computed on the basis of historical forecast errors by the RBNZ and the Treasury would be even more negatively skewed given the more negative coefficients in the above regressions above.

38. This section illustrates the fan charts for the forecasts for the 2018 mid-year OECD Economic Outlook. These forecasts predict growth in New Zealand to remain solid at 3\% over 2018 and 2019, with the commentary noting that there are both upside and downside risks to this projection.

39. To construct a benchmark the first set of fan charts is computed based on the historical forecast errors by the OECD assuming that the errors are normally distributed and unbiased (even though this assumption is unlikely to hold, as outlined in Section 2) (Figure 6, panel A). This approach corresponds to that used by the Swedish Riksbank since 2007 to parameterise the fan charts for GDP growth and inflation published in their quarterly Monetary Policy Report (Riksbank, 2007) and that of the Treasury (Section 5.1).

40. A second fan chart using probit probabilities of a downturn is then computed using the methodology described in Sections 3-5 above (Figure 6, panel B). Given the solid economic outlook, the estimated probability of a severe downturn for New Zealand based on the variables available at the time was close to zero. Consequently, the fan chart using probit probabilities of a future downturn is symmetric, but narrower than the fan chart based on historical forecast errors. The fan chart is narrower because it is calibrated using forecast errors from non-downturn periods only, which are on average smaller than forecast errors over the entire sample. 
Figure 6. Fan charts for the mid-year 2018 Economic Outlook NZ GDP growth forecast

(A) Based on historical forecast errors

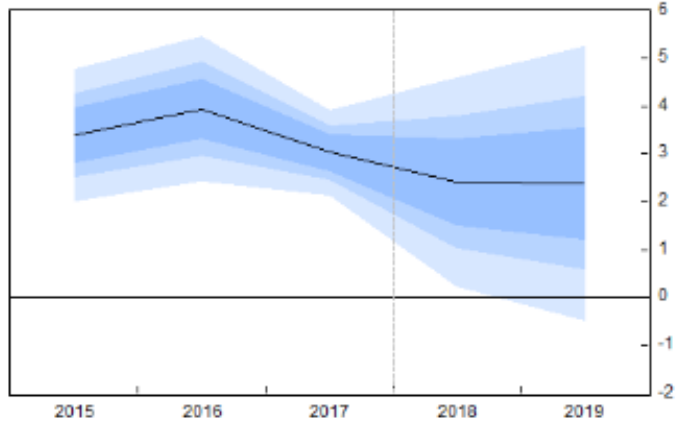

(B) Using probit probabilities of a future downturn

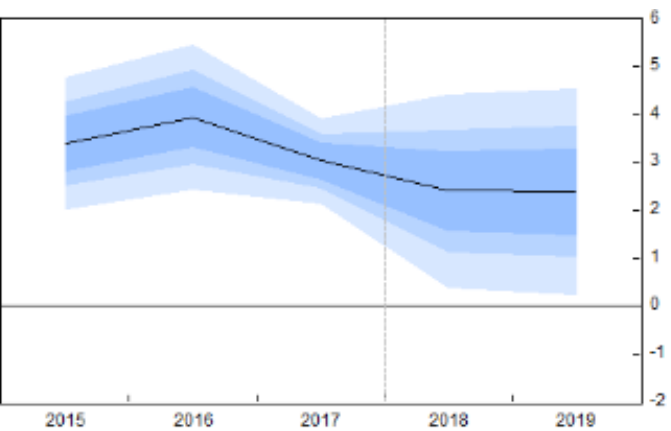

$\square$ GDP forecasts $\square$ 90\% interval
$\square$ 70\% interval $\square$ interval

Note: Shaded blue areas show successively the $50 \%, 70 \%$ and $90 \%$ prediction intervals. The solid black line is the outturn up to 2017 and the projection for 2018 and 2019, as reported in the mid-year 2018 Economic Outlook. The prediction intervals around the historical growth path reflect the extent to which historical estimates of GDP growth are subsequently revised.

\subsection{Fan charts prior to the Global Financial Crisis}

41. A demanding test of the usefulness of the fan chart approach is to see how the approach would have performed just prior to the GFC. Firstly, fan charts are illustrated for the forecasts for 2008 and 2009 published in the mid-year 2008 Economic Outlook. These forecasts did not include any explicit quantitative assessment of risk, with the commentary for New Zealand noting that "risks appear symmetric".

42. This exercise could be performed in two ways. Firstly, an in-sample exercise using currently-available data is run over the entire sample. It is not possible to conduct an outof-sample exercise as there are insufficient data to estimate the probit model. This insample exercise illustrates the information that the current models would have provided in the lead up to the GFC and potentially what information these models could provide if a similar set of circumstances is encountered over coming years.

43. The benchmark fan chart based on historical forecast errors suggests that the 2008 and 2009 GDP outturns are below or just within the $90 \%$ prediction interval of the fan chart (Figure 7, panel A). However, the fan chart using probit probabilities of a downturn is significantly skewed to the downside (Figure 7, panel B). At the time of the publication of the mid-year 2008 forecast, the annualised probability of a downturn in 2009 was $85 \%$, implying the risks to the GDP forecast were strongly tilted to the downside. There is a combination of factors underlying this non-zero downturn probability and downwards skew for the mid-year 2008 forecasts. Some of these factors had been occurring for several years, including the increasingly negative yield curve slope, the overshooting of inflation since 2004, increasing credit growth in New Zealand since 2003 and in OECD countries since 2005 and positive house price inflation in OECD countries. Other factors were more recent occurrences such as the increase in the unemployment rate from 2008Q2. Consequently, the GDP outturns for both 2008 and 2009 were encompassed in the 50-70\% prediction interval of the fan chart. 
Figure 7. Fan charts for the mid-year 2008 Economic Outlook NZ GDP growth forecast

(A) Based on historical forecast errors

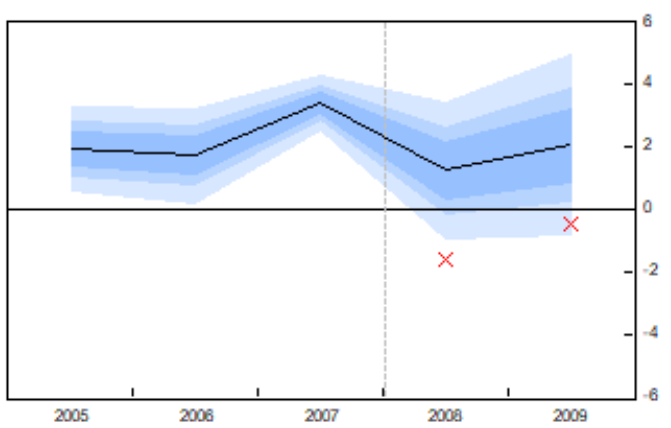

(B) Using probit probabilities of a future downturn

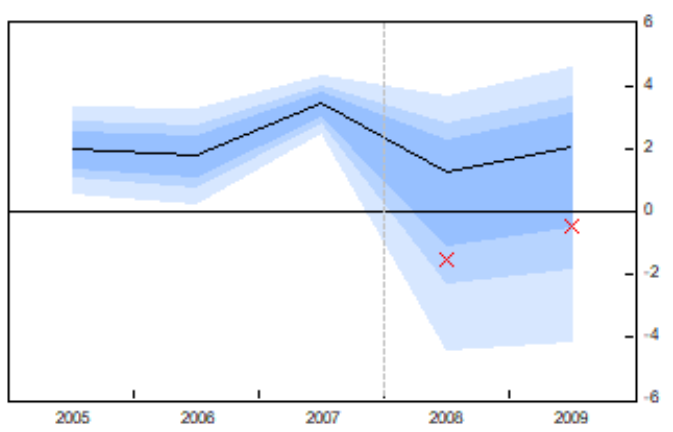

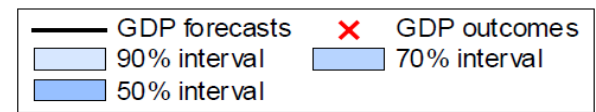

Note: Shaded blue areas show successively the $50 \%, 70 \%$ and $90 \%$ prediction intervals. The solid black line is the outturn up to 2007 and the projection for 2008 and 2009, as reported in the mid-year 2008 Economic Outlook. The red crosses show the outturn according to the Economic Outlook published in the year following the first outturn of the data. The prediction intervals around the historical growth path reflect the extent to which historical estimates of GDP growth are subsequently revised.

44. The same exercise is repeated for the year-end 2007 Economic Outlook forecasts which cover a two-year horizon to 2009 (Figure 8). No explicit quantitative assessment of risk was included with the forecasts. However, the commentary in the Economic Outlook alongside the forecasts for New Zealand suggested that "Uncertainty is high" and that "External risks would appear to be mostly on the downside... domestic risks loom more on the upside...".

45. Similarly, the benchmark fan chart based on historical forecast errors suggests that the 2008 and 2009 GDP outturns are below or at the bottom of the fan chart (Figure 8, panel A). The fan chart calculated using probit probabilities of a downturn is skewed to the downside, given the risk of a downturn for the shorter-sample model of $48 \%$ for 2008 and 57\% for 2009 (Figure 8, panel B). Consequently, the outturns for 2008 and 2009 were encompassed within the fan chart. 
Figure 8. Fan charts for the year-end 2007 Economic Outlook NZ GDP growth forecast

(A) Based on historical forecast errors

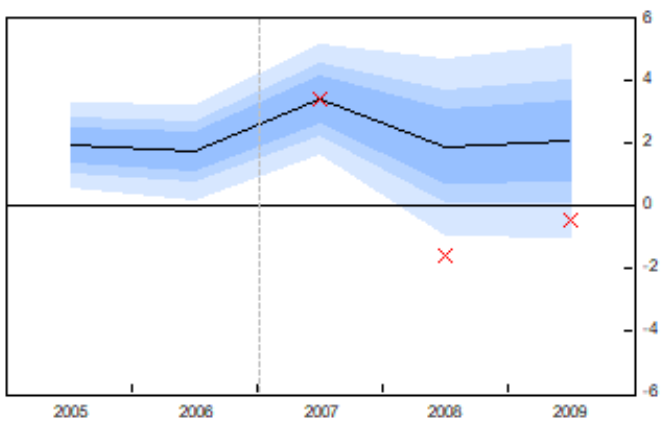

(B) Using probit probabilities of a future downturn

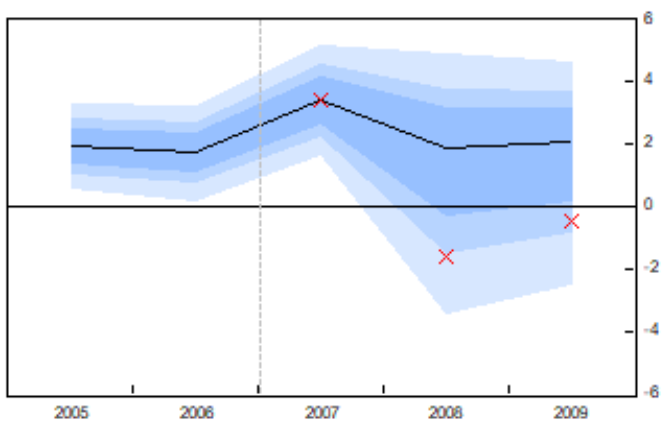

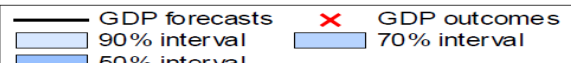

Note: Shaded blue areas show successively the $50 \%, 70 \%$ and $90 \%$ prediction intervals. The solid black line is the outturn up to 2006 and the projection for 2007, 2008 and 2009, as reported in the Autumn 2007 Economic Outlook. The red crosses show the outturn according to the Economic Outlook published in the year following the first outturn of the data. The prediction intervals around the historical growth path reflect the extent to which historical estimates of GDP growth are subsequently revised.

46. Another demanding test would be to conduct an out-of-sample exercise estimated up to 2007Q3 and 2008Q1. As noted above, there is an insufficient number of downturns over the 1988 to $2007 \mathrm{Q} 3$ period over which to estimate the models. As such the sample period must be extended, which may pose concerns due to the major structural changes that occurred over the 1980s. A start date of 1980Q3 was chosen as the volatility in the macroeconomic data over the 1970s makes obtaining significant coefficients difficult.

47. Unsurprisingly, over this time period, most of the estimated coefficients in the probit models for both New Zealand and OECD credit growth are insignificant. This result suggests that the relationship between credit growth and downturns in New Zealand has changed over the past ten years.

\section{Conclusions}

48. This paper has followed a method for designing fan charts based on historical forecast errors which recognises that forecasters have a poor track record in predicting future downturns. This methodology uses the probabilities from probit models at different forecast horizons to quantify the risk of a future downturn. The relationship between these probabilities and past forecast errors is then used to parameterise the downwards skew in a fan chart.

49. This method is illustrated for New Zealand. Early warning indicators in the probit models include the slope of the yield curve, unemployment, CPI inflation and credit-GDP ratio as well as OECD-wide aggregates of the credit-GDP ratio and real house prices. Fan charts estimated for the forecasts published in the mid-year 2018 Economic Outlook are symmetric while those estimated in the lead up to the GFC using in-sample data illustrate downwards skew. 


\section{References}

Bank of England (2005), "Assessing the MPC's Fan Charts", Bank of England Quarterly Bulletin. http://www.bankofengland.co.uk/publications/Documents/quarterlybulletin/qb05030 1.pdf

Blix, M. and P. Sellin (1998), "Uncertainty Bands for Inflation Forecasts", Sveriges Riksbank Working Paper Series, No. 65.

Boero, G., Smith, J., and Wallis, K. F. (2015), "The Measurement and Characteristics of Professional Forecasters' Uncertainty”, Journal of Applied Econometrics, vol. 30: 1029-1046. doi: 10.1002/jae.2400.

Brash, D. (1996) "New Zealand's Remarkable Reforms", speech delivered at the Fifth Annual Hayek Memorial Lecture, June.

Britton, E., P. Fisher and J. Whitley (1997), "Asymmetry, Risks and a Probability Distribution of Inflation", Bank of England Quarterly Bulletin, http://www.bankofengland.co.uk/archive/Documents/historicpubs/qb/1998/qb98010 1.pdf

Casella, G. and R. Berger (2002), Statistical inference, Second Edition, Duxbury Advanced Series.

Cross, P. and D. Wyman (2011), "The Relationship between Monthly, Quarterly and Annual Growth Rates", Canadian Economic Observer, June.

Dovern, J. and C. Ziegler (2008), "Predicting Growth Rates and Recession. Assessing US Leading Indicators Under Real Time Conditions”, Working Paper 1397, Kiel University.

Estrella, A. (2007), "Why does the Yield Curve Predict Output and Inflation?" Economic Journal, 115:722-44.

Estrella, A and F. S. Miskin (1997), "The Predictive Power of the Term Structure of Interest Rates in Europe and the United States: Implications for the European Central Bank”, European Economic Review, 41:1375-1401.

Estrella, A., A. P. Rodrigues and S. T. Schich (2003), "How Stable is the Predictive Power of the Yield Curve? Evidence from Germany and the United States", Review of Economics and Statistics, 85:629-644.

Fornari, F. and W. Lemke (2010), "Predicting Recession Probabilities with Financial Variables over Multiple Horizons", ECB Working Paper Series, No. 1255, October.

Hall, V. B. \& C. John McDermott (2016), "Recessions and recoveries in New Zealand's post-Second World War business cycles", New Zealand Economic Papers, 50:3, 261280.

Hermansen, M and O. Röhn (2016), "Economic Resilience: The Usefulness of Early Warning Indicators in OECD countries", OECD Journal: Economic Studies, No. 1, 
Vol. 2016, Issue, 1, pp. 9-35. OECD Publishing, Paris.

DOI: http://dx.doi.org/10.1787/eco_studies2016-5jg2ppjrd6r3

IMF (2009), World Economic Outlook, April.

Lewis, M and C. J. McDermott (2016), "New Zealand's Experience with Changing its Inflation Target and the Impact on Inflation Expectations", Reserve Bank of New Zealand Discussion Paper Series, 2016/07, May.

McDemott, J. (2017), "The Value of Forecasting in an Uncertain world" speech delivered to the New Zealand Manufacturers and Exporters Association (NZMEA) in Christchurch,15 May.

New Zealand Treasury (2011), Budget Economic and Fiscal Update, May.

New Zealand Treasury (2016), "MEI Special Topic: Illustrating Forecast Uncertainty", Treasury Staff, Issued, May. https://treasury.govt.nz/publications/staff-insight/mei-special-topic-illustratingforecast-uncertainty

OECD (1994), OECD Economic Surveys: New Zealand 1994, OECD Publishing, Paris, https://doi.org/10.1787/eco_surveys-nzl-1994-en.

OECD (1996), OECD Economic Surveys: New Zealand 1996, OECD Publishing, Paris, https://doi.org/10.1787/eco surveys-nzl-1996-en.

OECD (2007), OECD Economic Outlook, No. 82, Vol. 2007/2, November, OECD Publishing, Paris. DOI: https://doi.org/10.1787/16097408

OECD (2008), OECD Economic Outlook, No. 83, Vol. 2008/1, June, OECD Publishing, Paris. DOI: http://dx.doi.org/10.1787/eco_outlook-v2008-1-en

Parkyn, O. (2010), “Estimating New Zealand's Structural Budget Balance”, New Zealand Treasury Working Paper 10/08, November.

Reddell and Sleeman (2008), "Some Perspectives on Past Recessions", RBNZ Bulletin, Vol. 71, No. 2, June 2008, p5-21.

Reserve Bank of New Zealand (2011), Monetary Policy Statement, March.

Reserve Bank of New Zealand (2014), Monetary Policy Statement, June.

Sveriges Riksbank (2007), "Calculation Method for Uncertainty Banks", Box in Chapter 1 of Monetary Policy Report 2007/1.

Turner D., T. Chalaux and H. Morgavi (2018), "Fan Charts around GDP Projections Based on Probit Models of Downturn Risk", OECD Economics Department Working Papers, 1521. 
Turner, D. (2017), "Designing Fan Charts for GDP Growth Forecasts to Better Reflect Downturn Risks, OECD Economics Department Working Papers, No. 1428, OECD Publishing, Paris. DOI: http://dx.doi.org/10.1787/e86f1bfc-en

Turner D. (2018), "The Use of Models in Macroeconomic Forecasting at the OECD", chapter in "Global Economic Modelling: A Volume in Honor of Laurence Klein", ed. P. Pauly, World Scientific.

Turner D. and T. Chalaux (2019), "Calibrating GDP Fan Charts Using Probit Models with a Comparison to the Approches of the Bank of England and Riksbank", OECD Economics Department Working Papers, No. xxxx, OECD Publishing, Paris.

Wallis, K. F. (2014), "The Two-Piece Normal, Binormal, or Double Gaussian Distribution: Its Origin and Rediscoveries", Statistical Science, Vol. 29, No. 1, pp. 106-112, https://projecteuclid.org/euclid.ss/1399645739

Wallis K F. (1999), "Asymmetric Density Forecasts of Inflation and the Bank of England's Fan Chart", National Institute Economic Review, January.

World Bank (2016), "Quantifying Uncertainties in Global Growth Forecasts", Special Focus 2 in Global Economic Prospects, June. 


\section{Annex A. Addlitional descriptive statistics and probit regressions}

\section{Table A1. Descriptive statistics for forecast errors}

(1996-2017, the period for which RBNZ forecasts are available, percentage points, unless otherwise specified)

(A) Year-ahead forecast errors published year-end

\begin{tabular}{lcccccc}
\hline & Mean error & $\begin{array}{c}\text { Mean absolute } \\
\text { error }\end{array}$ & RMSE & $\begin{array}{c}\%+\text { +ve errors } \\
\&>2 \times \text { RMSE }\end{array}$ & $\begin{array}{c}\text { \% errors -ve } \\
\&>2 \times \text { RMSE }\end{array}$ & Normality test \\
\cline { 2 - 7 } OECD & -0.1 & 1.2 & 1.7 & $0 \%$ & $9 \%$ & Not reject \\
RBNZ & -0.3 & 1.1 & 1.4 & $5 \%$ & $5 \%$ & Not reject \\
\hline
\end{tabular}

(B) Year-ahead forecast errors published mid-year

\begin{tabular}{lcccccc}
\hline & Mean error & $\begin{array}{c}\text { Mean absolute } \\
\text { error }\end{array}$ & RMSE & $\begin{array}{c}\text { \% errors +ve } \\
\&>2 \times \text { RMSE }\end{array}$ & $\begin{array}{c}\text { \% errors -ve } \\
\&>2 \times \text { RMSE }\end{array}$ & Normality test \\
\cline { 2 - 7 } OECD & -0.5 & 1.2 & 1.6 & $0 \%$ & $5 \%$ & Not reject \\
RBNZ & -0.5 & 1.1 & 1.5 & $0 \%$ & $5 \%$ & Not reject \\
\hline
\end{tabular}

(C) Two-year-ahead forecast errors published year-end

\begin{tabular}{lcccccc}
\hline & Mean error & $\begin{array}{c}\text { Mean absolute } \\
\text { error }\end{array}$ & RMSE & $\begin{array}{c}\text { \% errors +ve } \\
\&>2 \times \text { RMSE }\end{array}$ & $\begin{array}{c}\% \text { errors -ve } \\
\&>2 \times \text { RMSE }\end{array}$ & Normality test \\
\cline { 2 - 7 } OECD & -0.5 & 1.2 & 1.5 & $0 \%$ & $10 \%$ & Not reject \\
RBNZ & -0.7 & 1.3 & 1.7 & $0 \%$ & $5 \%$ & Not reject \\
\hline
\end{tabular}

Source: New Zealand Treasury, OECD Economic Outlook databases, Reserve Bank of New Zealand, authors' calculations 
Table A2. Descriptive statistics for forecast errors

(2002-2017, the period for which forecasts from the Treasury are available, percentage points, unless otherwise specified)

(A) Year-ahead forecast errors published year-end

\begin{tabular}{ccccccc}
\hline & Mean error & $\begin{array}{c}\text { Mean absolute } \\
\text { error }\end{array}$ & RMSE & $\begin{array}{c}\% \text { +ve errors } \\
\&>2 \times \text { RMSE }\end{array}$ & $\begin{array}{c}\% \text { errors -ve } \\
\&>2 \times \text { RMSE }\end{array}$ & Normality test \\
\cline { 2 - 6 } OECD & 0.3 & 1.1 & 1.5 & $0 \%$ & $6 \%$ & Not reject \\
RBNZ & -0.2 & 1.1 & 1.4 & $6 \%$ & $0 \%$ & Not reject \\
The Treasury & -0.2 & 1.1 & 1.4 & $0 \%$ & $6 \%$ & Not reject \\
\hline
\end{tabular}

(B) Year-ahead forecast errors published mid-year

\begin{tabular}{ccccccc}
\hline & Mean error & $\begin{array}{c}\text { Mean absolute } \\
\text { error }\end{array}$ & RMSE & $\begin{array}{c}\text { \% errors +ve } \\
\&>2 \times \text { RMSE }\end{array}$ & $\begin{array}{c}\% \text { errors -ve } \\
\&>2 \times \text { RMSE }\end{array}$ & Normality test \\
\cline { 2 - 7 } OECD & -0.5 & 1.2 & 1.5 & $0 \%$ & $6 \%$ & Not reject \\
RBNZ & -0.5 & 1.1 & 1.5 & $0 \%$ & $0 \%$ & Not reject \\
The Treasury & -0.3 & 1.0 & 1.4 & $0 \%$ & $6 \%$ & Not reject \\
\hline
\end{tabular}

(C) Two-year-ahead forecast errors published year-end

\begin{tabular}{ccccccc}
\hline & Mean error & $\begin{array}{c}\text { Mean absolute } \\
\text { error }\end{array}$ & RMSE & $\begin{array}{c}\text { \% errors +ve } \\
\&>2 \times \text { RMSE }\end{array}$ & $\begin{array}{c}\text { \% errors -ve } \\
\&>2 \times \text { RMSE }\end{array}$ & Normality test \\
\cline { 2 - 7 } OECD & -0.2 & 1.2 & 1.4 & $0 \%$ & $7 \%$ & Not reject \\
RBNZ & -0.6 & 1.3 & 1.8 & $6 \%$ & $0 \%$ & Not reject \\
The Treasury & -0.7 & 1.1 & 1.7 & $0 \%$ & $7 \%$ & Not reject \\
\hline
\end{tabular}

Source: New Zealand Treasury, OECD Economic Outlook databases, Reserve Bank of New Zealand, authors' calculations. 
Table A3. Probit regressions of a severe downturn in NZ at different horizons

\begin{tabular}{|c|c|c|c|c|c|}
\hline \multirow{3}{*}{$\begin{array}{l}\text { Binary dependent variable: } \\
1=\text { severe downturn, } 0=\text { otherwise }^{1}\end{array}$} & \multirow{3}{*}{$\begin{array}{l}\text { Standard } \\
\text { deviation }\end{array}$} & \multicolumn{4}{|c|}{ Probit regression at horizon of Q quarters } \\
\hline & & $\mathrm{Q}=2$ & $\mathrm{Q}=4$ & $\mathrm{Q}=6$ & $\mathrm{Q}=8$ \\
\hline & & 1988-2018Q3 & 1988-2018Q3 & 1988-2018Q3 & 1989Q3-2018Q3 \\
\hline Constant & & $-2.00 * * *$ & $-2.22 * * *$ & $-2.06 * * *$ & $-2.32 * * *$ \\
\hline Yield curve slope ${ }^{2}$ & 1.50 & $-0.32 * * *$ & & & \\
\hline $\begin{array}{l}\text { Unemployment rate } \\
1 \text {-year change }\end{array}$ & 1.01 & $0.73 * * *$ & $0.84 * * *$ & $0.58 * * *$ & \\
\hline CPI inflation & & & & & \\
\hline Difference from target midpoint ${ }^{3}$ & 1.83 & & & & $0.63 * * *$ \\
\hline $\begin{array}{l}\text { Private credit-to-GDP ratio } \\
\text { 3-year annual average change }\end{array}$ & 3.10 & & $0.09(-)$ & $0.08(-)$ & $0.06(-)$ \\
\hline $\begin{array}{l}\text { OECD private credit-to-GDP ratio } \\
3 \text {-year annual average change }\end{array}$ & 1.80 & $0.35 * * *$ & $0.14(-)$ & $0.10(-)$ & $0.05(-)$ \\
\hline $\begin{array}{l}\text { OECD real house prices } \\
\text { 3-year annual change }\end{array}$ & 2.65 & & $0.19 * *$ & $0.21 * * *$ & $0.21 * * *$ \\
\hline McFadden R-sqd & & 0.42 & 0.4 & 0.31 & 0.41 \\
\hline $\begin{array}{l}\% \text { of correct predictions } \\
\\
\text { Downturns } \\
\text { Non-downturns }\end{array}$ & & $\begin{array}{l}81 \% \\
91 \% \\
79 \% \\
\end{array}$ & $\begin{array}{l}78 \% \\
87 \% \\
76 \% \\
\end{array}$ & $\begin{array}{l}71 \% \\
87 \% \\
67 \% \\
\end{array}$ & $\begin{array}{l}73 \% \\
87 \% \\
69 \% \\
\end{array}$ \\
\hline
\end{tabular}

Notes:

1) A severe downturn episode is defined as a series of quarters in which GDP per capita falls in both the initial and final quarter of the episode and GDP per capita falls cumulatively by at least 2 percentage points.

2) The yield curve slope is defined as the interest rate on 10-year government bonds less the short-term policy rate.

3) The midpoint of the Reserve Bank of New Zealand target band is assumed from 1990 onwards. For the pre-inflation-targeting period from 1980-1990, the target midpoint in 1990 of $4 \%$ is assumed as the midpoint.

4) Credit to the private, non-financial sector from banks.

5) Credit to the private, non-financial sector from all sectors.

6) Predictions categorised according to a $15 \%$ probability threshold.

Statistical significance of coefficients at the $1 \%, 5 \%$ and $10 \%$ levels are denoted by '***', ‘**' and '*”,

For the probit regression at an horizon of $Q$ quarters $(Q=2,4,6$ or 8), explanatory variables enter the equations at different horizons due to the timing of data releases. The yield curve variable is lagged by $\mathrm{Q}-1$ quarters, unemployment and CPI variables are lagged by Q quarters, house price variables are lagged by $Q+1$ quarters, while credit variables are lagged by $Q+2$ quarters.

Source: OECD Analytical Database and OECD Resilience Database. 
Table A4. Regressions of forecast errors for New Zealand on downturn probabilities

(A) OECD - estimated over the period for which forecasts from the RBNZ are available

\begin{tabular}{|c|c|c|c|c|}
\hline \multirow[b]{2}{*}{$\begin{array}{l}\text { Forecast published in } \\
\text { Forecast horizon }\end{array}$} & \multicolumn{4}{|c|}{ Dependent variable: forecast error, $\epsilon_{t}{ }^{(s, t+i)}$} \\
\hline & $\begin{array}{c}\text { Mid-year } \\
\text { current-year }\end{array}$ & $\begin{array}{c}\text { Year-end } \\
\text { year-ahead }\end{array}$ & $\begin{array}{c}\text { Mid-year } \\
\text { year-ahead }\end{array}$ & $\begin{array}{c}\text { Year-end } \\
\text { 2-years-ahead }\end{array}$ \\
\hline Sample period & $1995-2017$ & $1996-2017$ & $1996-2017$ & $1997-2017$ \\
\hline \multirow[t]{2}{*}{ Intercept term $\left(\beta_{0}\right)$} & 0.02 & 0.00 & -0.24 & -0.26 \\
\hline & - & - & - & - \\
\hline \multirow[t]{2}{*}{ Downturn probability $\mathrm{P}_{\mathrm{t}}^{(\mathrm{s}, \mathrm{t}+\mathrm{i})},\left(\beta_{1}\right)$} & 3.31 & 2.87 & -2.15 & 0.23 \\
\hline & - & - & - & - \\
\hline Dummy for 1998 & $\begin{array}{c}-4.70 \\
*\end{array}$ & $\begin{array}{c}-4.46 \\
*\end{array}$ & -2.15 & -2.79 \\
\hline R-sqd adjusted & 0.20 & 0.17 & 0.39 & 0.35 \\
\hline
\end{tabular}

(B) OECD - estimated over the period for which forecasts from the New Zealand Treasury are available

\begin{tabular}{lcccc}
\hline & \multicolumn{4}{c}{ Dependent variable: forecast error, $\epsilon_{\mathrm{t}}{ }^{(\mathrm{s}, \mathrm{t}+\mathrm{i})}$} \\
\cline { 2 - 5 } $\begin{array}{l}\text { Forecast published in } \\
\text { Forecast horizon }\end{array}$ & $\begin{array}{c}\text { Mid-year } \\
\text { current-year }\end{array}$ & $\begin{array}{c}\text { Year-end } \\
\text { year-ahead }\end{array}$ & $\begin{array}{c}\text { Mid-year } \\
\text { year-ahead }\end{array}$ & $\begin{array}{c}\text { Year-end } \\
\text { 2-years-ahead }\end{array}$ \\
\cline { 2 - 5 } Sample period & $2001-2017$ & $2002-2007$ & $2002-2007$ & $2003-20017$ \\
\hline Intercept term $\left(\beta_{0}\right)$ & 0.37 & 0.43 & 0.14 & 0.06 \\
& - & - & - & - \\
Downturn probability $\mathrm{P}_{\mathrm{t}}^{(\mathrm{s}, \mathrm{t}+\mathrm{i})},\left(\beta_{1}\right)$ & -0.74 & -1.49 & -3.39 & -3.16 \\
& - & - & $*$ & $*$ \\
R-sqd adjusted & 0.03 & 0.06 & 0.24 & 0.21 \\
\hline
\end{tabular}

(C) RBNZ - estimated over the period for which forecasts from the New Zealand Treasury are available

\begin{tabular}{|c|c|c|c|c|}
\hline \multirow[b]{2}{*}{$\begin{array}{l}\text { Forecast published in } \\
\text { Forecast horizon } \\
\text { Sample period }\end{array}$} & \multicolumn{4}{|c|}{ Dependent variable: forecast error, $\epsilon_{t}{ }^{(s, t+i)}$} \\
\hline & $\begin{array}{l}\text { Mid-year } \\
\text { current-year } \\
2001-2017\end{array}$ & $\begin{array}{c}\text { Year-end } \\
\text { year-ahead } \\
2002-2017 \\
\end{array}$ & $\begin{array}{c}\text { Mid-year } \\
\text { year-ahead } \\
\text { 2002-2017 }\end{array}$ & $\begin{array}{c}\text { Year-end } \\
\text { 2-years-ahead } \\
\text { 2003-2017 }\end{array}$ \\
\hline Intercept term $\left(\beta_{0}\right)$ & 0.10 & 0.23 & -0.07 & 0.19 \\
\hline & - & - & - & - \\
\hline Downturn probability $\mathrm{P}_{\mathrm{t}}^{(\mathrm{s}, \mathrm{t}+\mathrm{i})},\left(\beta_{1}\right)$ & $\begin{array}{c}-0.65 \\
-\end{array}$ & $\begin{array}{c}-3.36 \\
-\end{array}$ & $\begin{array}{c}-4.01 \\
*\end{array}$ & $\begin{array}{c}-6.40 \\
*\end{array}$ \\
\hline R-sqd adjusted & 0.06 & 0.40 & 0.38 & 0.53 \\
\hline
\end{tabular}

Note: Statistical significance of coefficients at the $1 \%, 5 \%$ and $10 \%$ levels are denoted by '***', '**' and '*',

Source: New Zealand Treasury, OECD Economic Outlook databases, Reserve Bank of New Zealand, authors' calculations. 